تعيين قواعد بهرهبردارى از مخزن سد درودزن با استفاده از شبكه عصبى

تطبيقيذير مبتنى بر سيستم استنتاج فازى (ANFIS)

محمدحسن طراز كار "، منصور زيبايى'، غلامرضا سلطانى' و مسعود نوشادى'

(تاريخ دريافت: 10/11

حكيده

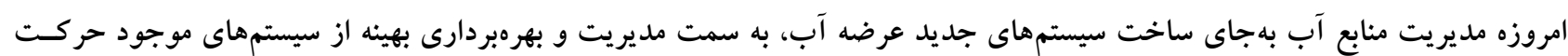

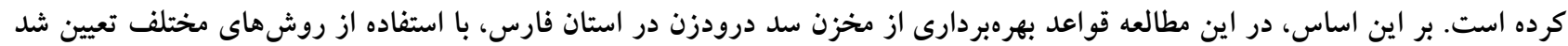

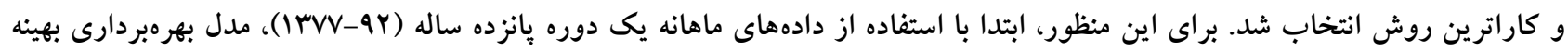

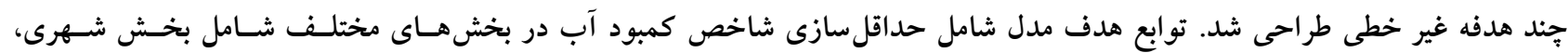

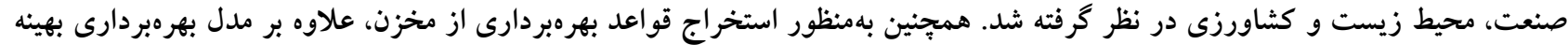

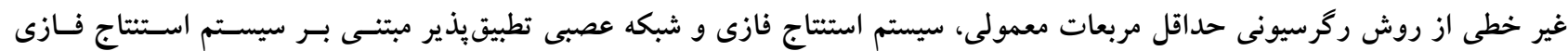

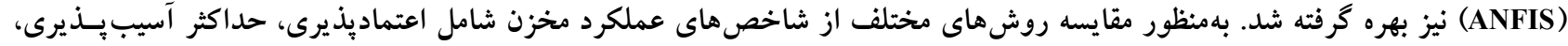

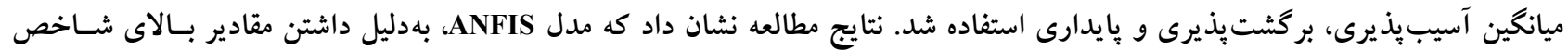

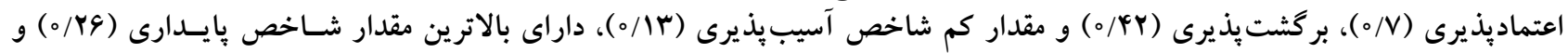

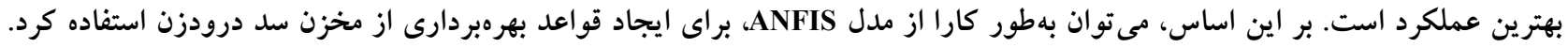

وازههاى كليدى: منحنى فرمان، سيستم استنتاج فازى، شبكه عصبى فازى، شاخص عملكرد مخزن

1. كروه اقتصاد كشاورزى، دانشكده كشاورزى، دانشخاه شيراز r. كروه مهندسى آب، دانشكده كشاورزى، دانشخاه شيراز

* : مسئول مكاتبات: بِّت الكترونيكى: Tarazkar@shirazu.ac.ir 
عصبى مصسنوعى (Artificial Neural Network) تحـت عنـوان شـبكه عصـبى تطبيـق يـذير مبتنى بــر سيسـتم اسـتنتاج فــازى (Adaptive Network-based Fuzzy Inference System (ANFIS)) در مطالعات مختلف در زمينـه بهـرهبــردارى بهينـه و استخراج قو اعد بهرهبردارى از مخزن سد، مورد استفاده قرار گيـرد. مـدل

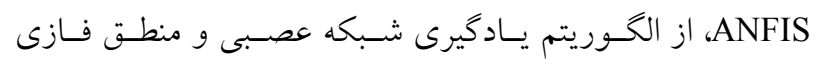
بهمنظور نخاشـت غيـر خطى بــين فضـاى ورودى و خروجسى استفاده مى كند و در قالـب يـك سيسـتم، هـر دو مزيـت زبــانى سيستم استنتاج فازى و توانايى يـاد گيرى شـبكههـاى عصسبى را

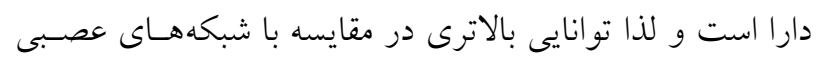
مصنوعى و سيستم استتناج فازى دارد (Y). موسوى و همكـاران روش ركرسيون خطى، رگرسـيون فـازى و مهـل ANFIS را در استخراج منحنى فرمان سد دز مقايسه كردند ( (Y). نتايج مطالعه نشان داد در بلند مدت، مدل ANFIS نسبت بـه سـاير روشهـا عملكرد بهترى در استخراج قوانين بهــرهبــردارى از مخـزن ســـ

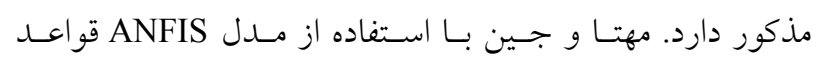
بهرهبردارى بهينه از يك مخزن جندمنظوره در كشور هند شـامل تأمين آب شـرب خـانكى، آب كشـاورزى و نيـروى برقـابى را طراحى كردند (19). نتايج مطالعسه نشـان داد كـه مــل ANFIS توانايى بالايى در استخراج منحنسى فرمـان ســ دارد. صـفوى و همكاران منحنى فرمان سد زايندهرود را با استفاده از روشهـــ برنامهريزى يويا، برنامهريزى بوياى فازى، سيستم استنتاج فـازى و روش ANFIS استخر اج و مقايسه كردند (YO). نتـايج مطالعـه نشان داد كه مدل ANFIS عملكرد بهترى در مقايسـه بـا سـاير روشها در استخراج منحنى فرمان سد دارد. سلطانى و همكاران با توجه به مشكالات كيفى و كمى سد ه1

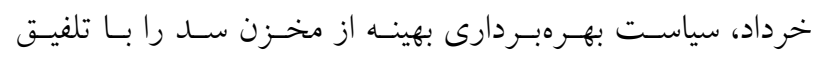

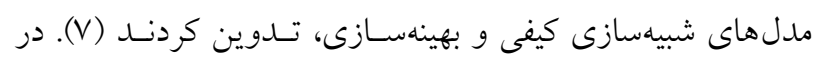
اين مطالعه از مدل ANFIS براى شبيهسازى كيفى مخزن اسـتفاده

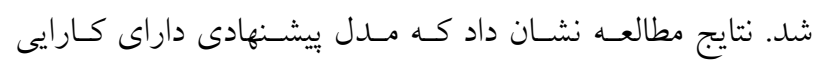
مناسب در كاهش زمان اجرا و بهبود كيفيت آب اسـت. نـورانى و همكاران (9) بهرهبردارى بهينه از سيستم دو مخزنه (ســ شـهريار

\section{مقدمه} سدها يكى از مهمترين منابع تأمين و ذخيـرهسـازى آب جهـت مصارف شهرى، صنعتى، كشـاورزى و زيسـتمحيطى هسـتند

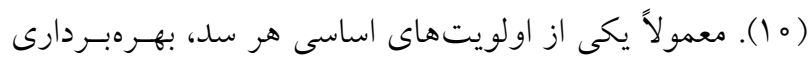

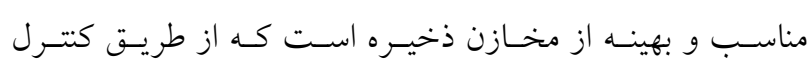
خروجى از مخزن صـورت مسى كيـرد. ميسزان رهاسـازى آب از مخزن در هر ارتفاع يا حجم ذخيره آب در مخزن، با استفاده از محزي

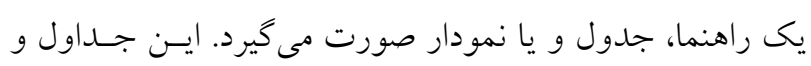
يا نمودارها بهعنوان دسـتور العمل هــاى بهـــبــردارى از مخــازن

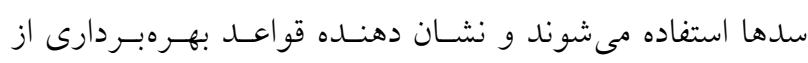
مخزن بوده و به منحنى فرمان سد معروف هستند (4). وجود عدم قطعيت و عدم دقت در متغيرهاى بهرهبـردارى

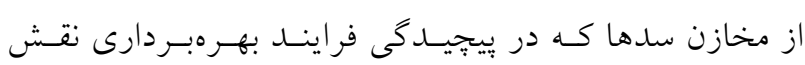
عمدهاى دارند و با تئورىهاى احتمـال قابـل تحليـل نيسـتند،

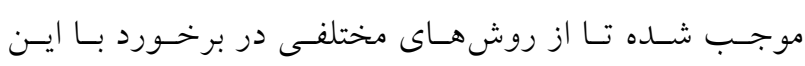
مشكات استفاده شود. يكى از روش هاى در نظر كرفتن عـدم قطعيت در مدلهاى بهرهبردارى از مخزن كه در مطالعات اخير

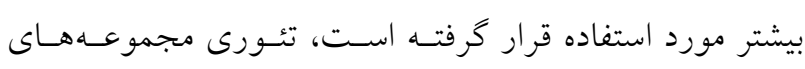
فـازى اسـت (Y). بعـــ از كسـترش تئسورى فــازى، محققــان

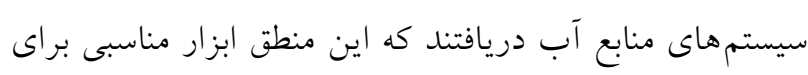

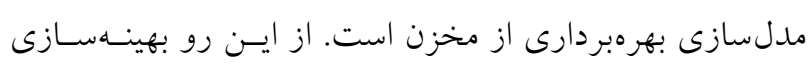
فـازى (Fuzzy Optimization)، ركرسـيون فـازى و سيسـتم اسـتنتاج فـازى (Fuzzy Inference System) در بسـيارى از مطالعات مختلـف در زمينـهـ بهــــبــردارى و اسـتخراج قواعـــ بهرهبردارى از مخزن، مورد استفاده قرار گرفتند (r). نتايج مطالعات مختلف نشان داده است كه سيستم اسـتنتاج

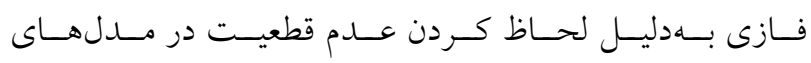
بهرهبردارى از مخزن، داراى عملكرد بهترى در استخراج قواعـد

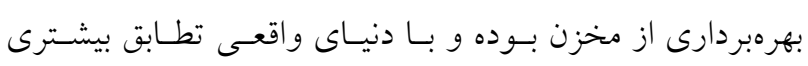
دارند. نتايج مطلـوب و توانـايى بـالاى سيستم اسـتنتاج فـازى در زمينه بهرهبردارى از مخزن و استخراج قواعد بهرهبـردارى از

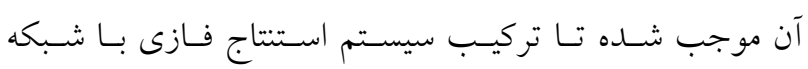


مناسب، تخليه آب از مخزن سد صورت مى يذيرد. عـلاوهبـر آن

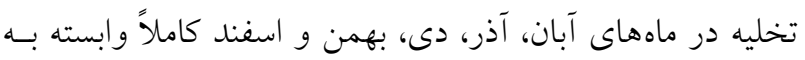
ريزشهاى جوى است و در صورت وجود ريزشهاى مناسـب

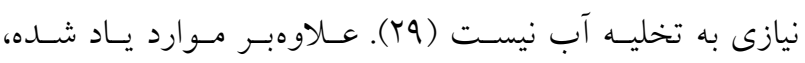

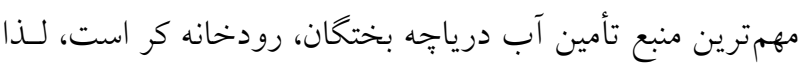

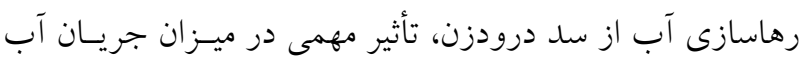

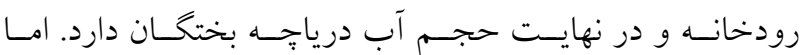

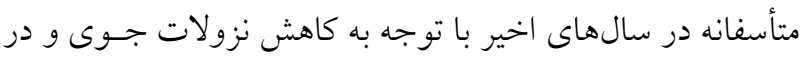

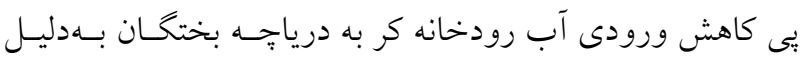

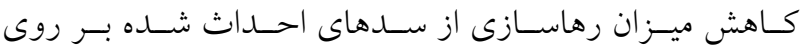

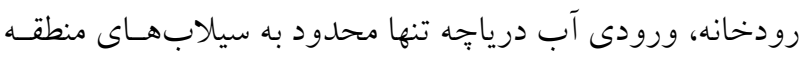

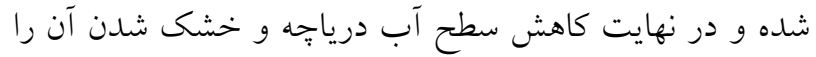
موجب شده اسـت (م). در شـكل (1)، نمـاى شـماتيك شـبكه آبيارى سد درودزن آورده شده است. كانال اصلى شبكه آبيارى درودزن از محـل خروجسى نيروكـاه سد آغاز شده و پس از طى مسيرى به طول بال كيلومتر بـه سـازه

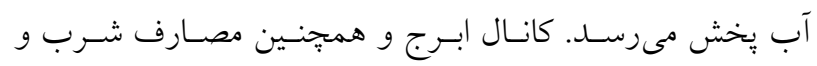

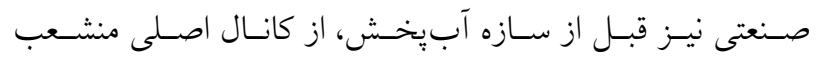

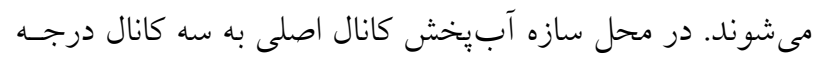
اول به نامهاى كانال اوليه سمت راست (موسوم به كانال هـامون)،

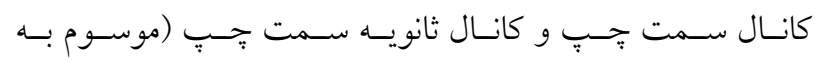

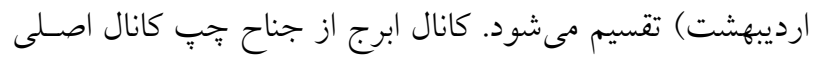

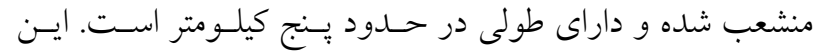
كانال عبا9 الهكتار از اراضى كشاورزى زيردست ســ درود زن را تحت يوشش قرار مى

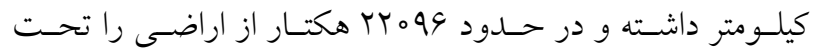
يوشش خود قرار مىدهد. كانال هامون طولى معسادل ب ب كيلـومتر

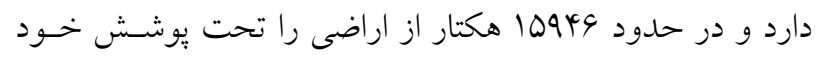

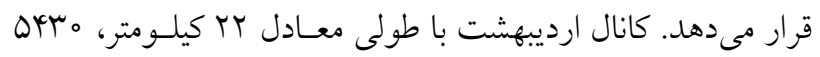

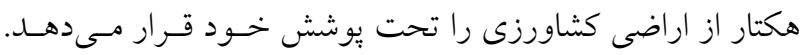

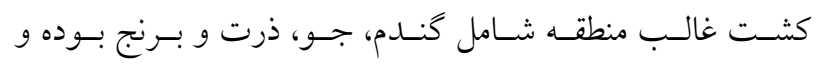

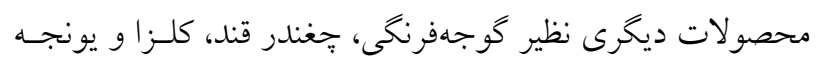

و سد سفيدرود) حوضه آبريز سفيدرود در شمال ايران، با استفاده

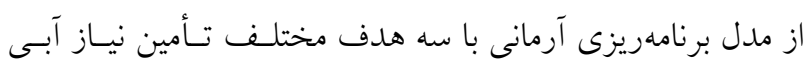

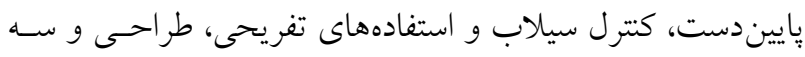

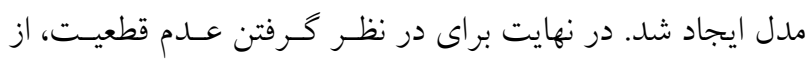

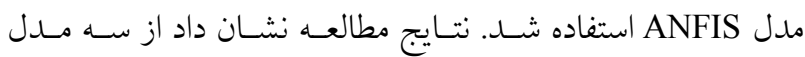

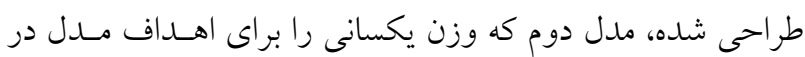

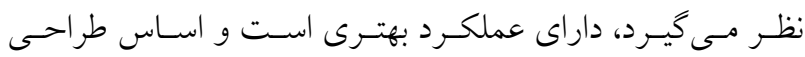

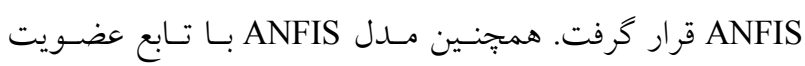

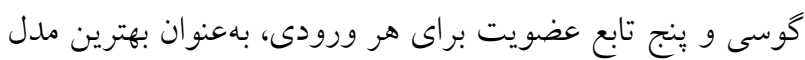

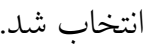
در اين مطالعه بهمنظور استخراج قواعد بهرهبردارى از مخزن

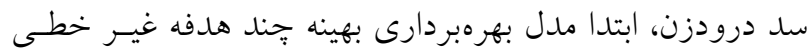

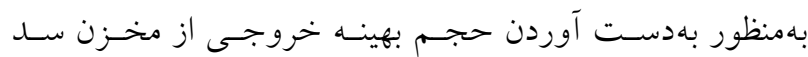

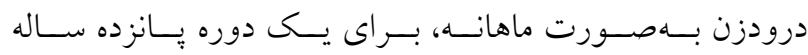

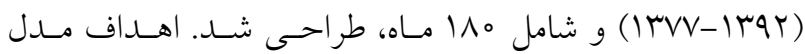
مذكور بهترتيب شامل حداقلسازى شـاخص كمبـود آب بـراى

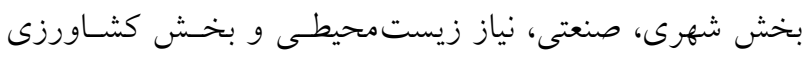

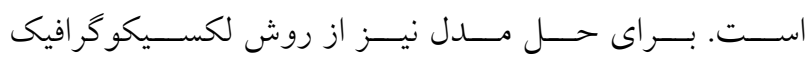

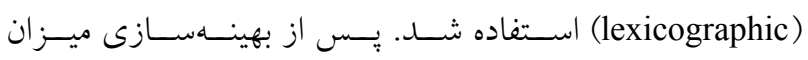

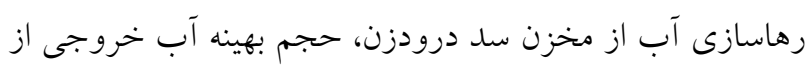

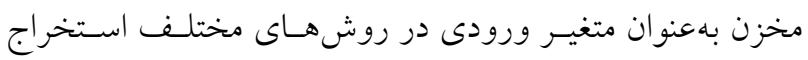
قواعد بهرهبردارى از مخزن، مورد استفاده قرار خرفت.

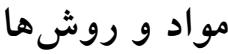

سد مخزنى درودزن در م 10 كيلومترى شمال غرب شيراز و بـر روى رودخانه كر احداث شده است. منطقه مـورد مطالعهـ بـين

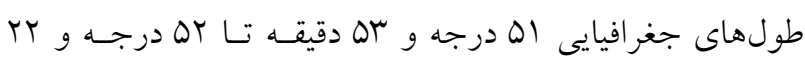

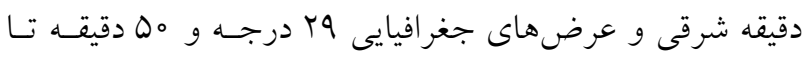

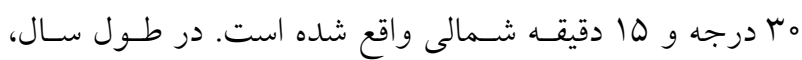

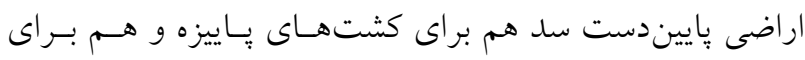

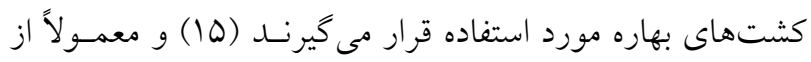

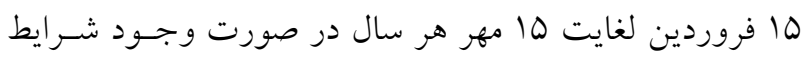




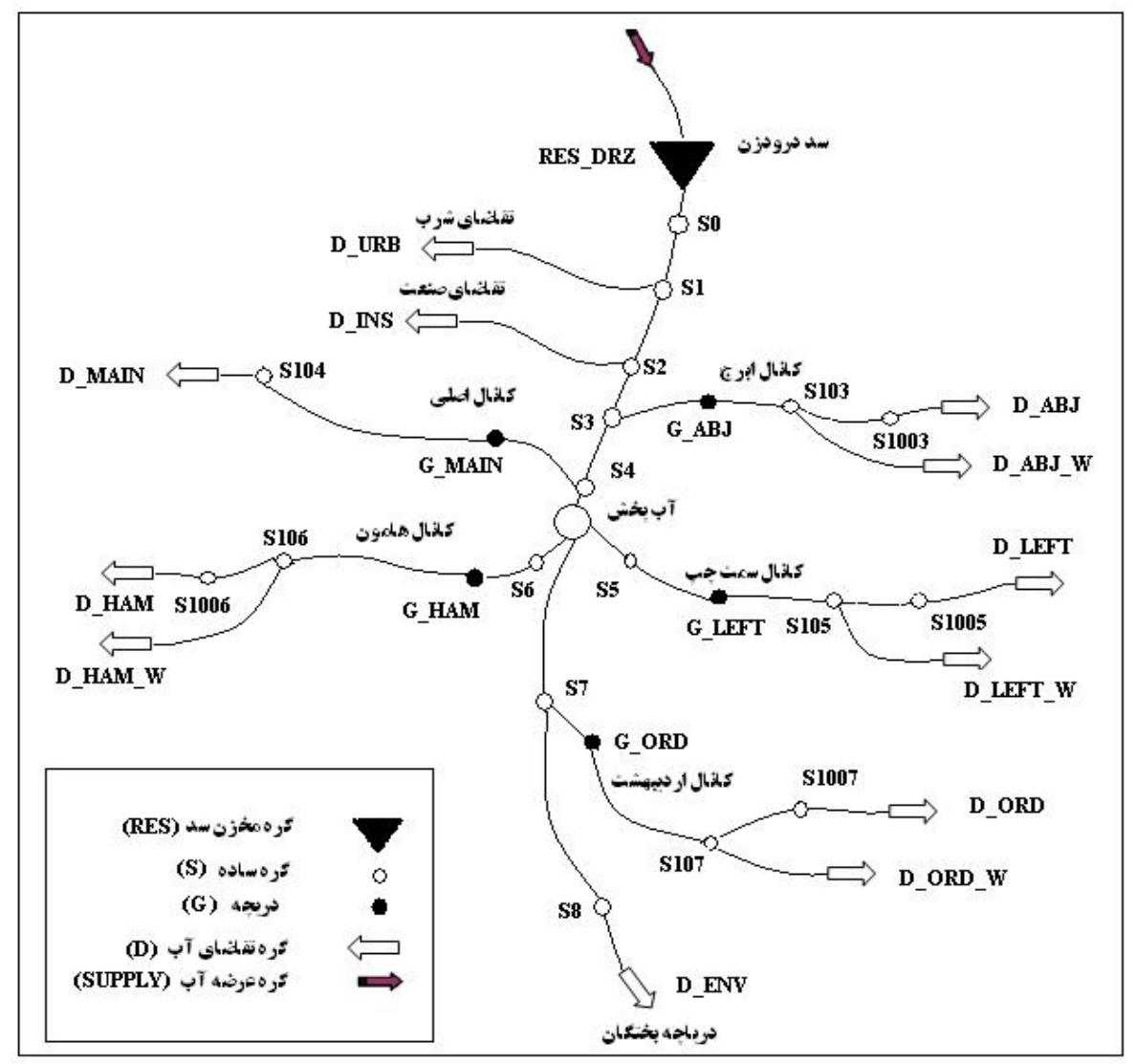

شكل 1. نماى شماتيك شبكه آبيارى سد درودزن

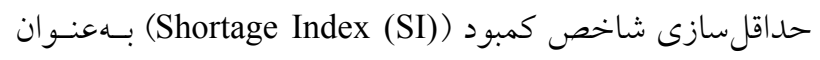

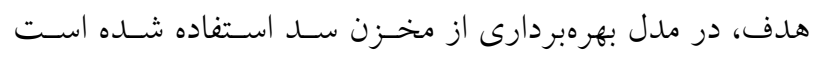

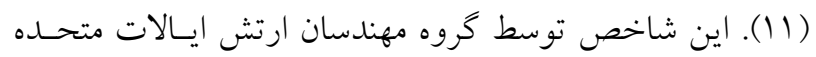
آمريكا ارائه شده و بهصورت رابطه (1) است: Min SI $=\sum_{t=1}^{T}\left(\frac{R_{t}-D_{t}}{D_{t}}\right)^{r}$

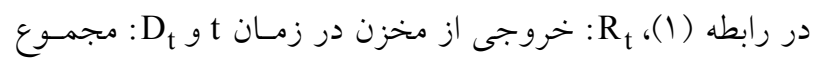

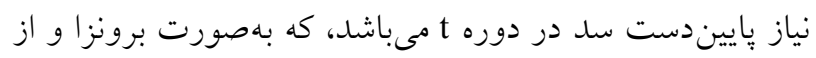

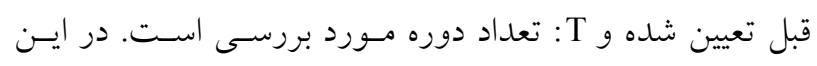

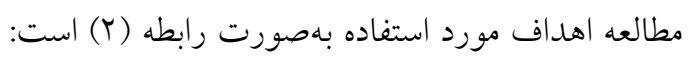
Min $Z_{1}=S_{1}=\sum_{t=1}^{T}\left(\frac{R_{t}^{\text {urb }}-D_{t}^{\text {urb }}}{D_{t}^{\text {urb }}}\right)^{r}$

Min $\mathrm{Z}_{r}=\mathrm{SI}_{r}=\sum_{\mathrm{t}=1}^{\mathrm{T}}\left(\frac{\mathrm{R}_{\mathrm{t}}^{\text {ind }}-\mathrm{D}_{\mathrm{t}}^{\text {ind }}}{\mathrm{D}_{\mathrm{t}}^{\text {ind }}}\right)^{r}$

Min $Z_{r}=\operatorname{SI}_{r}=\sum_{t=1}^{T}\left(\frac{R_{t}^{\text {env }}-D_{t}^{\text {env }}}{D_{t}^{\text {env }}}\right)^{r}$
نيز در منطقه مطالعاتى كشت مىشود (^). همانطوركه بيان شد، طى سه دهه اخير مسأله بهرهبـــردارى مئس

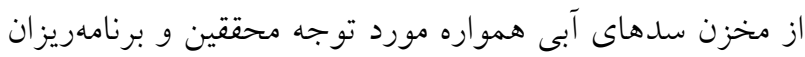
در اين زمينه بوده است. اما عليرغم ييشرفتهاى اخير در زمينـه

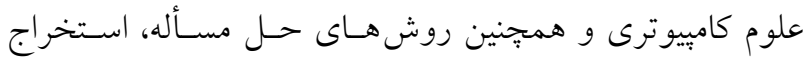
قواعد بهرهبردارى از مخزن سد همجنان مورد جالش باقى مانده

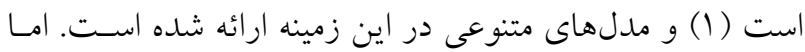
در تمام مدلهاى بهرهبردارى بهينه از مخزن سد متغيسر تصـميم جهت بهينهسازى، متوسط ميزان خروجى يا ميزان آب رها شــه

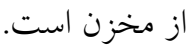
با توجه به اينكه، مدلهاى بهينـهسازى ارائسه شــه جهـت بهرهبردارى از مخازن سـدها در حالـت كلسى تخليـه مطلـوب را بهصورت تابعى از ذخيره مخزن و جريان ورودى به مخزن نشـان

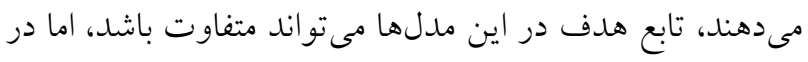

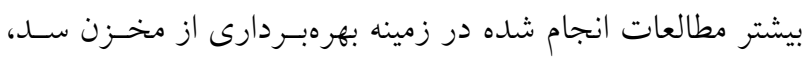


كه در تمام مر احل بهينه سازى بهرهبردارى از مخزن بايد موازنسه جرمى بين مقـادير ورودى و خروجسى و حجـم ذخيـره مخـزن فئن

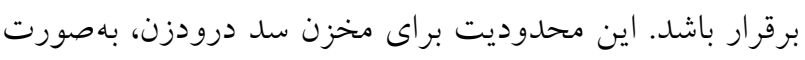

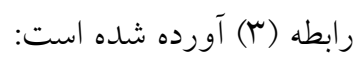

$\mathrm{S}(\mathrm{nl}, \mathrm{t})=\mathrm{S}(\mathrm{nl}, \mathrm{t}-1)+\sum_{\mathrm{n} \in \mathrm{in}} \mathrm{In}(\mathrm{nl}, \mathrm{t})-\sum_{\mathrm{n} \in \text { out }} \mathrm{R}(\mathrm{nl}, \mathrm{t})$

$-\sum_{\mathrm{n} \in \text { out }} \operatorname{Evp}(\mathrm{nl}, \mathrm{t})-\sum_{\mathrm{n} \in \mathrm{out}} \operatorname{spill}(\mathrm{nl}, \mathrm{t})$

در رابطه (T)، S(nl,t): حجم آب موجود در مخزن در دوره

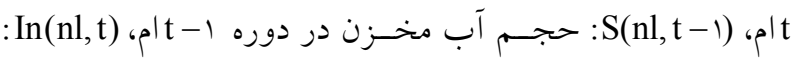

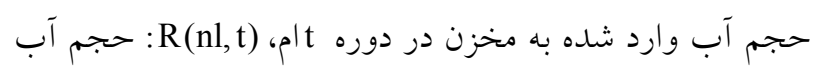

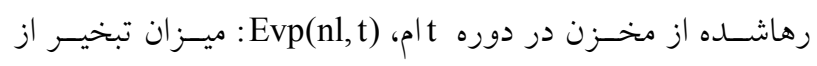

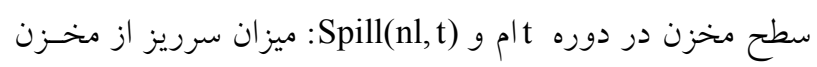

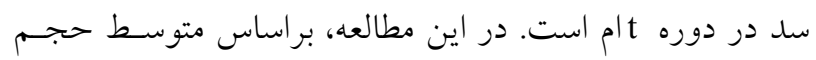

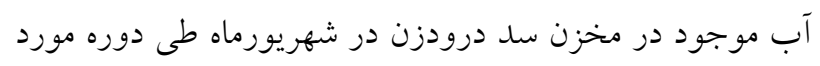

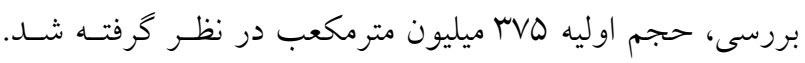

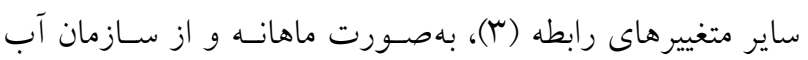

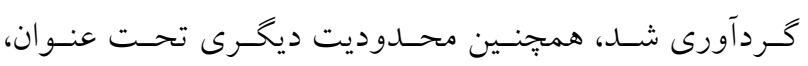
محسدوديت حجــم ذخيــه مخـزن بـه مــل اعمـال شـــ ايسن محسدوديت بيـان مسى كنـــ كـه در تمـام مر احسل بهينـهــازى و و

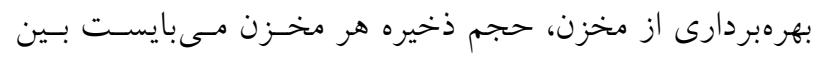

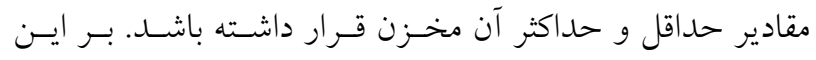

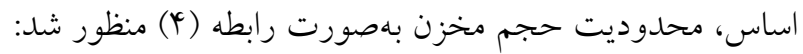
$\mathrm{S}_{\mathrm{Min}}(\mathrm{nl}, \mathrm{t}) \leq \mathrm{S}(\mathrm{nl}, \mathrm{t}) \leq \mathrm{S}_{\operatorname{Max}}(\mathrm{nl}, \mathrm{t})$

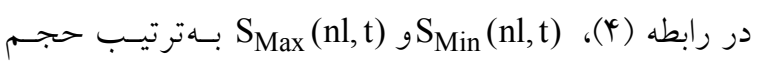
حداقل (حجم مرده) و حجـم حسداكثر مخـزن هسـتند. در ايسن

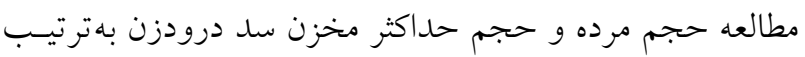

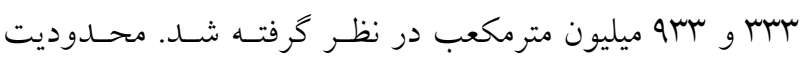

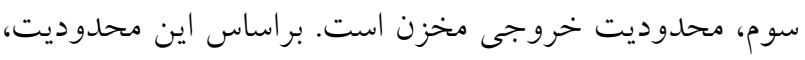

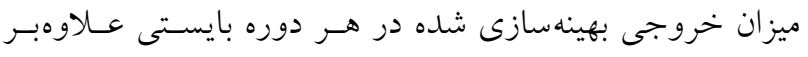

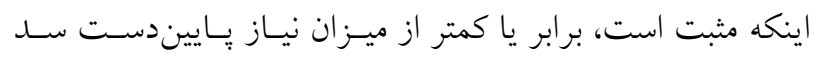
باشد و بهصورت رابطه (ه) بيان شده است: $\cdot \leq \mathrm{R}(\mathrm{nl}, \mathrm{t}) \leq \mathrm{D}(\mathrm{nl}, \mathrm{t})$
Min $Z_{\psi}=\mathrm{SI}_{\psi}=\sum_{\mathrm{t}=1}^{\mathrm{T}}\left(\frac{\mathrm{R}_{\mathrm{t}}^{\mathrm{agr}}-\mathrm{D}_{\mathrm{t}}^{\mathrm{agr}}}{\mathrm{D}_{\mathrm{t}}^{\mathrm{agr}}}\right)^{r}$

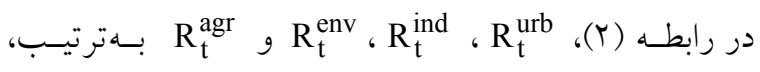
حجم آب رهاشده براى مصارف شهرى، صنعتى، زيستمحيطى رابل

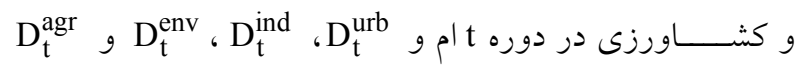

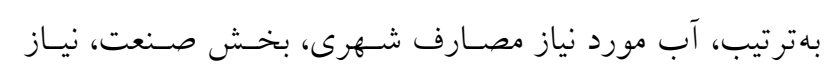

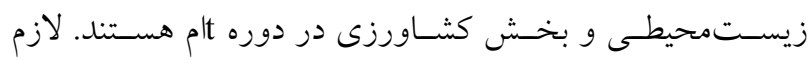
بهذكر است نيـاز مصـارف شهـرى ( توجه به راهاندازى خط دوم انتقال آب به شهر شيراز، وه ميليون

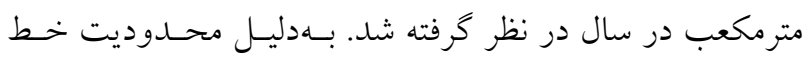

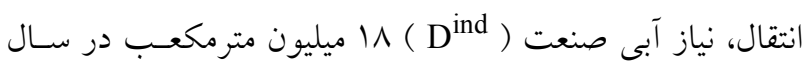

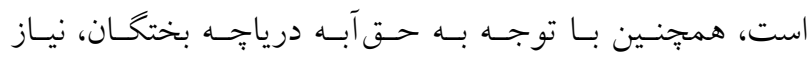

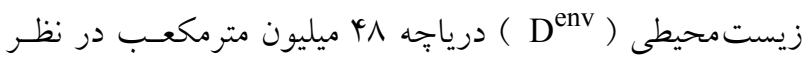

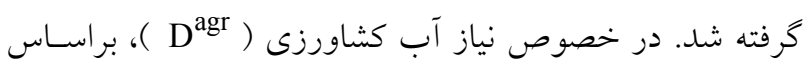

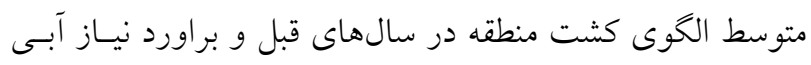

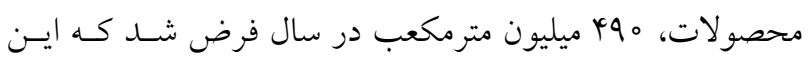

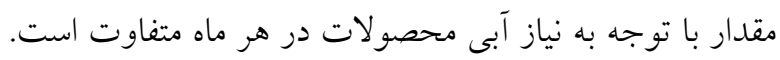

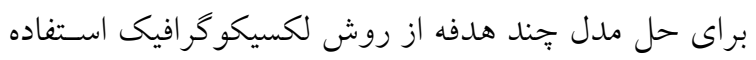

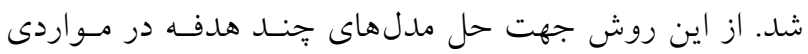

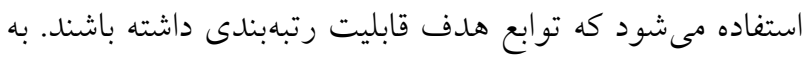

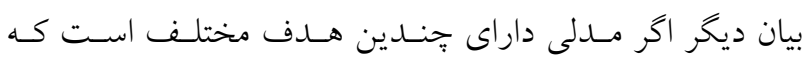

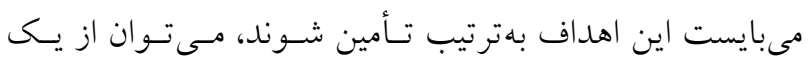

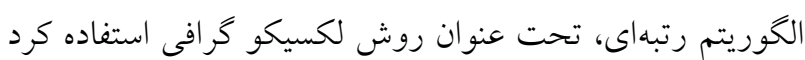

در هر مدل بهينهسازى، مقادير كليه متغيرهاى تصميم جهت

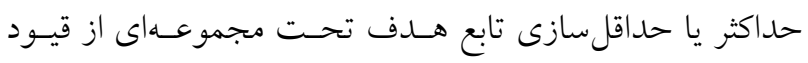

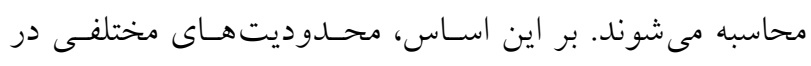

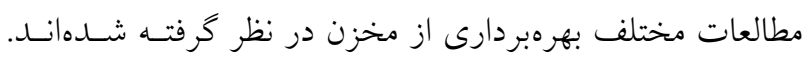

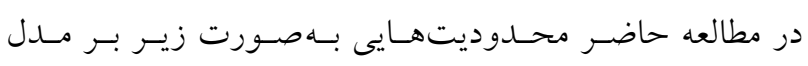

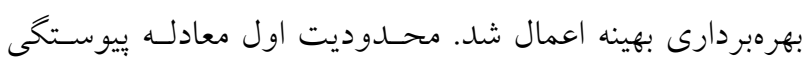

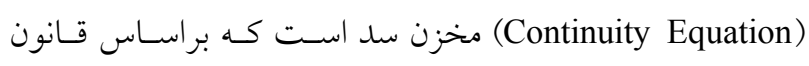

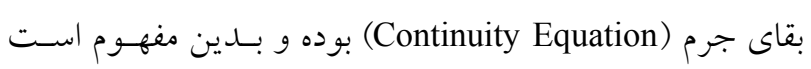


در مخزن در نظر كرفته مسى شـود (Y و צY). بـراى ايسن منظـور

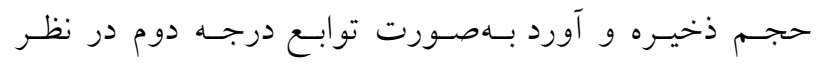

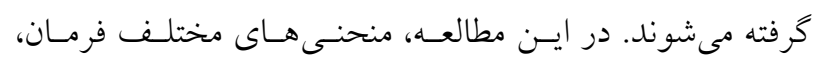

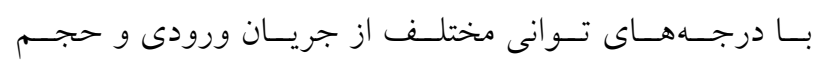

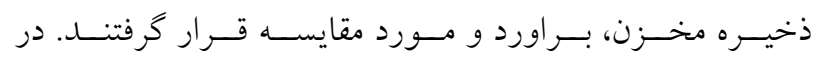

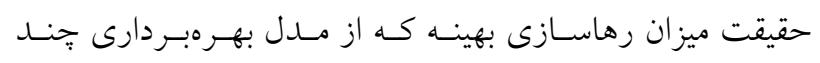

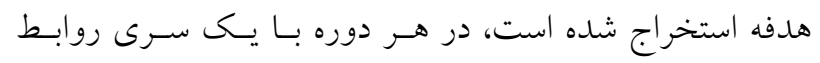

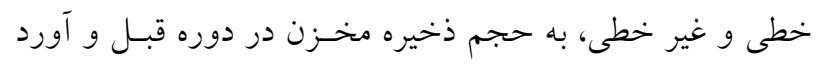

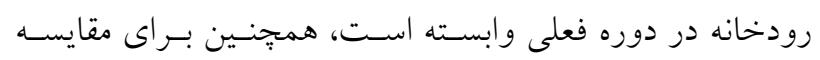

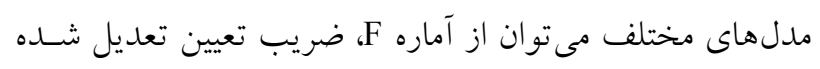

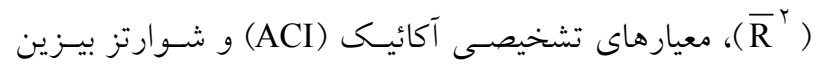
Root of Mean Square Error و و خطـاى يسيشبينى (SBC) و (RMSE)

به كارگيرى سيستم استتاج فازى در بهرهبردارى از مخزن سد

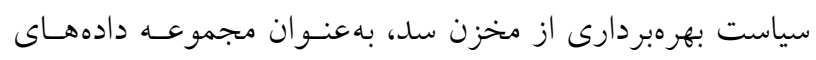
ورودى -خروجى جهت واسنجى قواعد فازى در سيستم استتناج

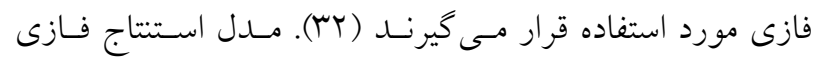

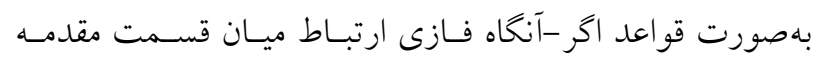

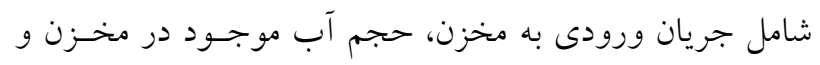

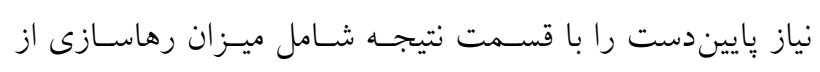

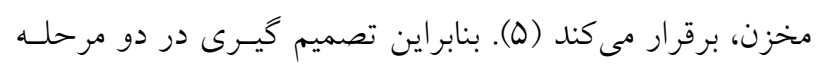

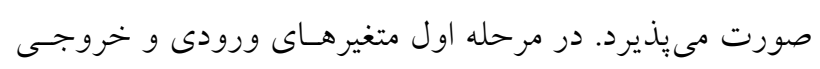

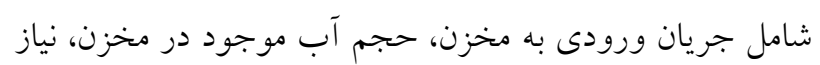

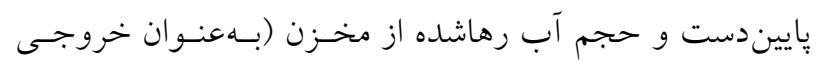

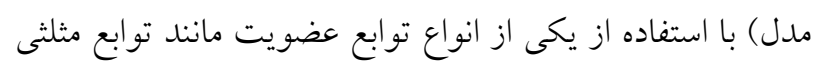

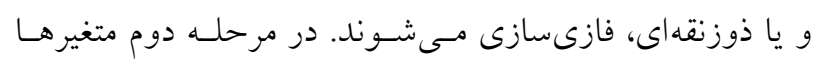

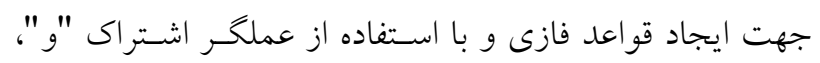

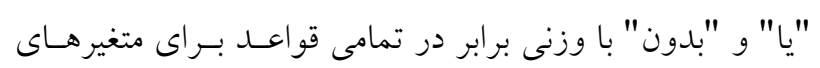

$$
\text { ورودى تركيب مىشوند. }
$$

دو نوع سيستم استتاج فازى براى نخاشت ورودى به خروجنى

وجود دارد كه شامل مدل فازى سـوكينو (Sugeno Fuzzy Model)
محدوديت جهارم محدوديت ظرفيت كانال ها اسـت و بيـان

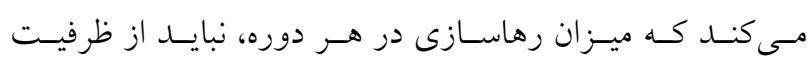

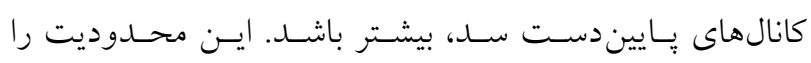
مى توان بهصورت رابطه (9) نشان داد:

$\mathrm{R}(\mathrm{nl}, \mathrm{t}) \leq \mathrm{C}_{\mathrm{Max}}$

در رابطه (9) C حداكثر ظرفيت كانال سد است. با توجه

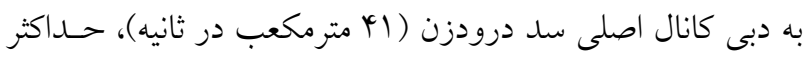

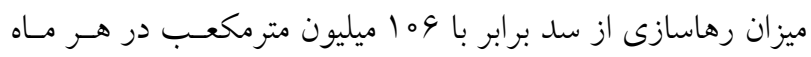
در نظر گرفته شد. محدوديت ديخر كه بهصورت رابطـه (9) بيـان

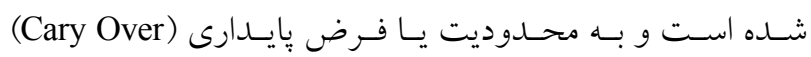

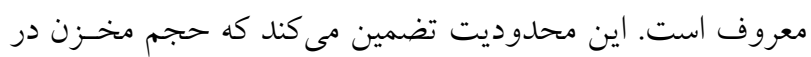
دوره اول و در انتهاى دوره آخر برابر خواهند بود. $\mathrm{S}_{\text {Final }}(\mathrm{nl}, \mathrm{t})=\mathrm{S}_{\text {First }}(\mathrm{nl}, \mathrm{l})$

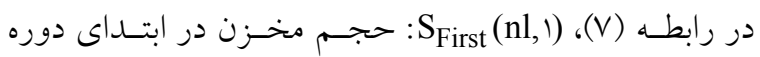

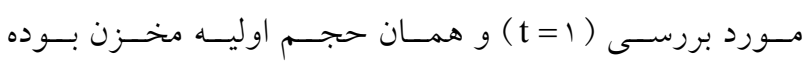
و SFinal

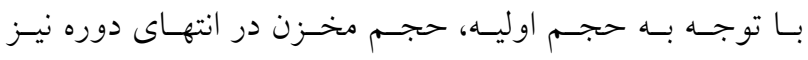
مىبايست برابر با MVQ ميليون مترمكعب باشد. در اغلب مخـازن

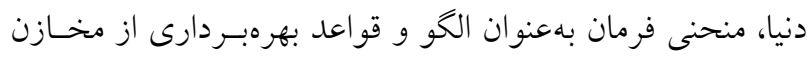

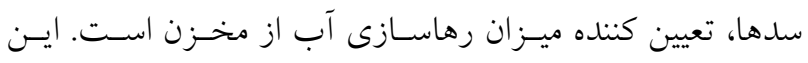

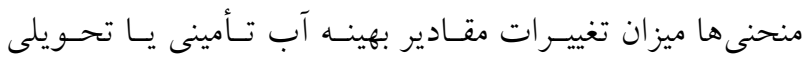

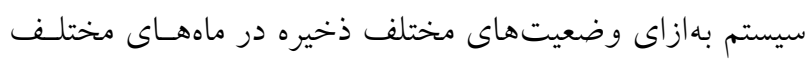

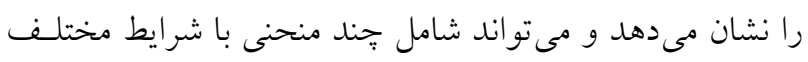

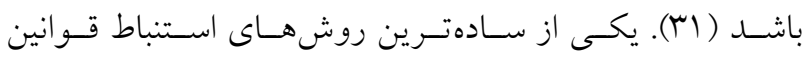

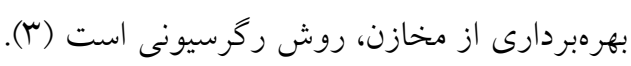
معمولترين شكل هاى منحنى فرمان عبارتند از منحنى فرمان

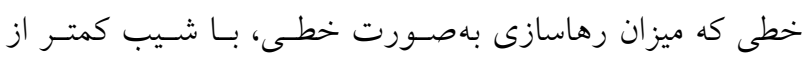

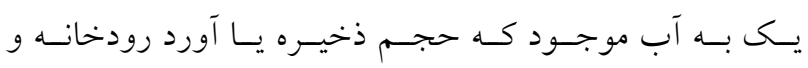

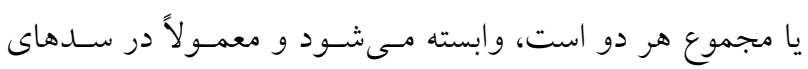

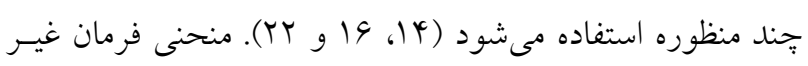

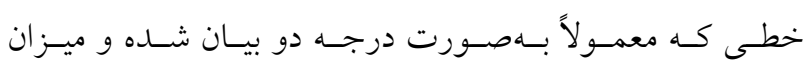

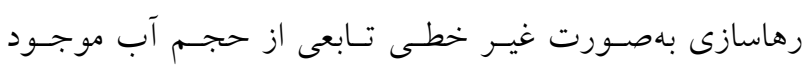




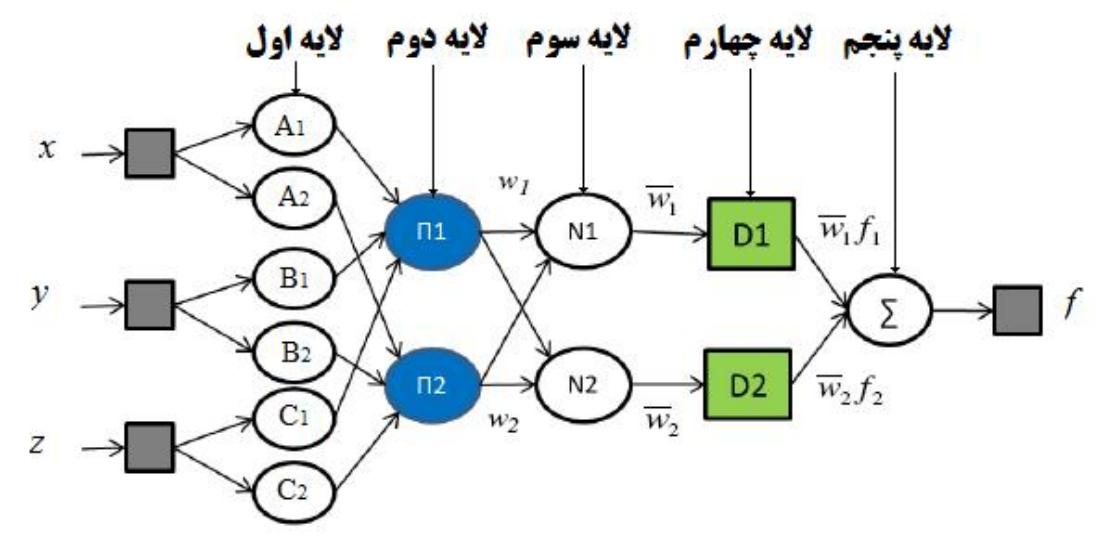

شكل Y. ساختار شماتيك شبكه ANFIS

همانطوركه در شكل (Y) مشـاهده مسى شـود، سـه ورودى

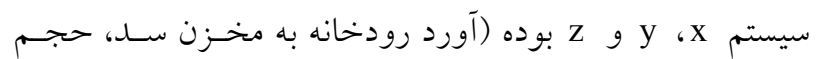
آب موجود در مخـزن و تقاضـاى آب در يـاييندسـت سـد) و خروجى آن (حجم آب رها شده از مخزن سد) با f نشـان داده شده است و دو قانون اين سيستم نيز بـهــورت روابـط (N) و (9) قابل بيان هستند (YV)

If $\mathrm{x}$ is $\mathrm{A}_{1} \& \mathrm{y}$ is $\mathrm{B}_{1} \& \mathrm{z}$ is $\mathrm{C}_{\text {, }}$

then $\mathrm{f}=\mathrm{p}_{1} \mathrm{x}+\mathrm{q}_{1} \mathrm{y}+\mathrm{k}_{1} \mathrm{z}+\mathrm{r}_{1}$

If $\mathrm{x}$ is $\mathrm{A}_{Y} \& \mathrm{y}$ is $\mathrm{B}_{Y} \& \mathrm{z}$ is $\mathrm{C}_{Y}$

then $\mathrm{f}=\mathrm{p}_{\mathrm{Y}} \mathrm{x}+\mathrm{q}_{\mathrm{Y}} \mathrm{y}+\mathrm{k}_{\mathrm{Y}} \mathrm{z}+\mathrm{r}_{\mathrm{Y}}$

با توجه به شكل (Y)، سـاختار شـبكه ANFIS از يـنج لايسه

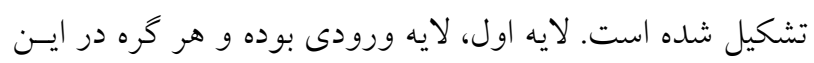

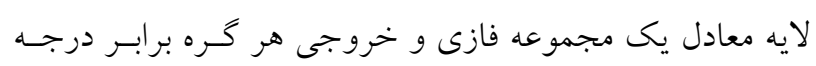

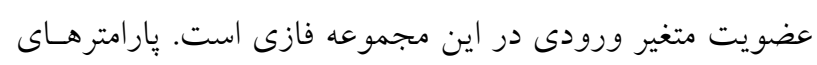
هر كره، تعيين كننده شكل تابع عضويت مجموعه فازى آن خـره هستند. توابع مختلفى شامل مثلثى، ذوزنقهاى، زنخولهاى و غيـره در طراحى شبكههاى عصبى - فازى مورد استفاده قرار مى گيرند

در لايسه دوم مقـادير ورودى بـهـ هـر خـره در هــم ضـرب

مىشوند و حاصل كه وزن قانونها است، بهدست مسى آيــ. هـر كره در لايه دوم درجه فعاليت يكى قانون را محاسـبه مسى كنـــ و

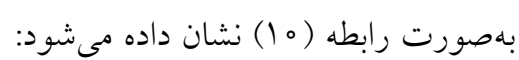

$\mathrm{Q}_{\mathrm{i}}^{r}=\mathrm{w}_{\mathrm{i}}=\mu_{\mathrm{Ai}}(\mathrm{x}) \times \mu_{\mathrm{Bi}}(\mathrm{y})$
و ممدانى (Mamdani Fuzzy Model) است. مدل استتّاج فـازى ممدانى، بهصورت اصول فازى بـا خروجسى برخــورد مسى كنـد. بلدين مفهوم كه تابع عضويت خروجى نيز مجموعه فازى اسـت

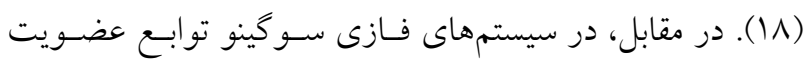
خروجى خطى و ثابت است. بـه بيـان سـاده در روش سـو گينو،

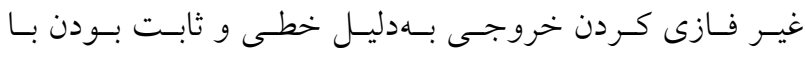
روش هاى محدودى امكانيذّير است (ro) و لذا در اين مطالعسه از سيستم استتناج فازى ممدانى استفاده شد.

شبكه عصبى تطبيقيذير مبتنـى بـر سيسـتم اسـتنتاج فـازى

(ANFIS)

اين نوع شبكهها كه از تلفيق شبكههاى عصبى مصنوعى و منطق

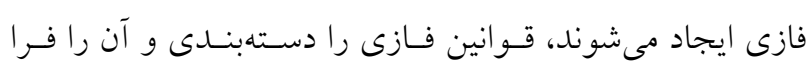

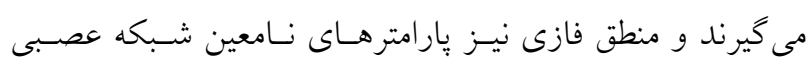

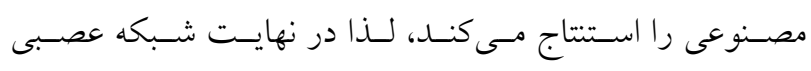
تطبيق يذير مبتنى بر سيستم استتاج فازى يا به اختصار ANFIS، از توانايى بالاترى در مقايسه با شبكههـاى عصسبى مصسنوعى و منطـق فــازى برخــوردار هســتند. در واقــع سيسـتم ANFIS بيادهسازى يك سيستم فازى نوع سو گنو بهصورت يك سـاختار

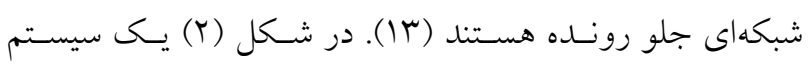
فازى سوگنو با دو ورودى، يك خروجى و دو قانون نشـان داده شده است. 
استفاده از مدلهاى بهينهسازى و شبيهسازى جهت بهـرهبـرداى از

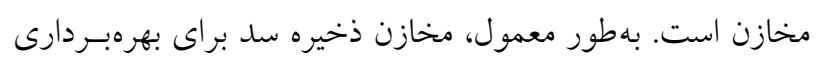

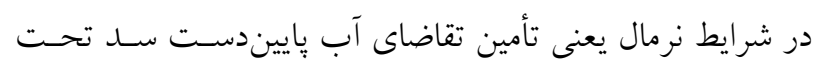

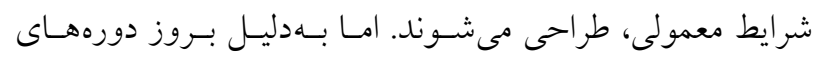

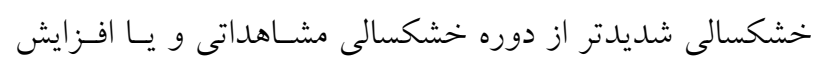

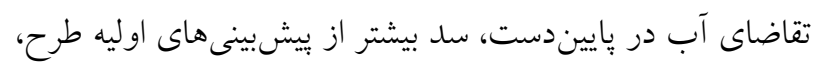

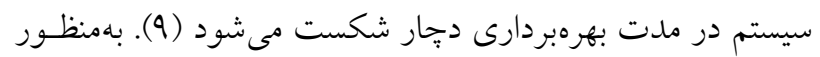

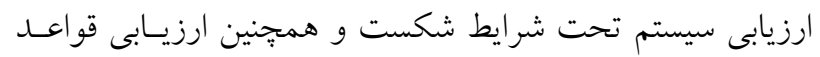

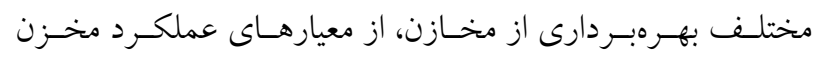

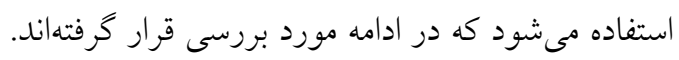

شاخص برگشت بذيرى (Resilience)

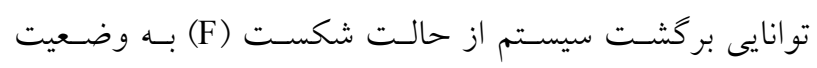
مطلوب و رضايتبخش (S)، بركشت يذيرى ناميده مى شود. اين

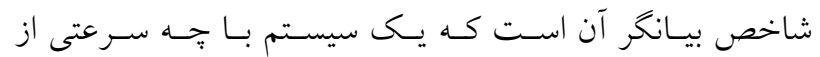
وضعيت شكست به وضعيت رضايت بخش برمى كردد (Y (I): $\beta=\frac{\operatorname{Prob}\left\{\mathrm{X}_{\mathrm{t}} \in \mathrm{F} \& \mathrm{X}_{\mathrm{t}+1} \in \mathrm{S}\right\}}{\operatorname{prob}\left\{\mathrm{X}_{\mathrm{t}} \in \mathrm{F}\right\}}$

شاخص اعتماديذيرى (Reliability)

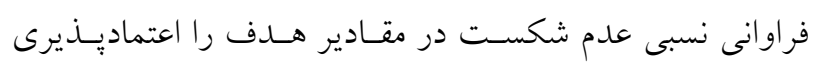

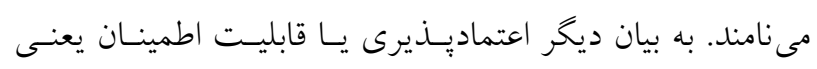
احتمال اينكه شكستى در بهرهبردارى از سيستم در مــدت زمـان يسان

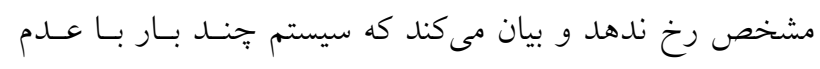

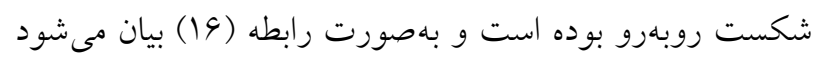

$\alpha=\operatorname{Prob}\{\mathrm{X} \in \mathrm{S}\}$

مقـدار بيشـتر ايسـن شـاخص، نشــاندهنـــه برتسرى قاعـــه

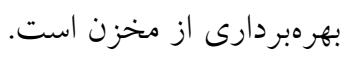

شاخص آسيبذيذيرى (Vulnerability)

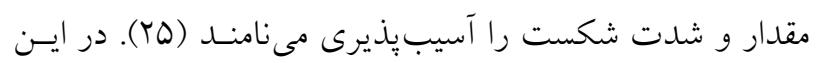

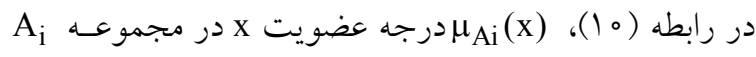

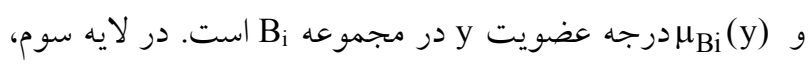

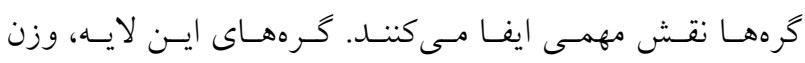

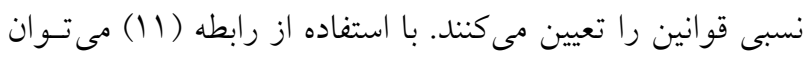
وزن نسبى گره iام را نسبت به كل وزن اين لايه محاسبه نمود: $Q_{i}^{r}=\bar{w}_{i}=\frac{w_{i}}{w_{1}+w_{r}}, \quad i=1, r$

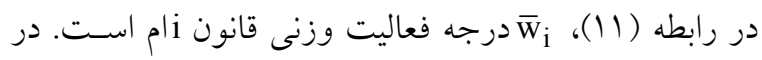

لايه جهارم نيز خروجى هر گره بهصورت رابطه (Y) (I) است: $Q_{i}^{\varphi}=\bar{w}_{i} f_{i}=\bar{w}_{i} \cdot\left(p_{i} x+q_{i} y+k_{i} z+r_{i}\right), \quad i=1, r$

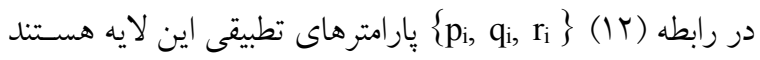
كه به نام يارامترهاى نتيجه يـا متعاقـب (Consequent Parameters)

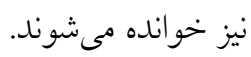
لايه ينجم، لايه خروجى ANFIS است. هر كره در اين لايه مقدار خروجى نهايى را بهصورت رابطه (با) محاسبه مسى كنـد.

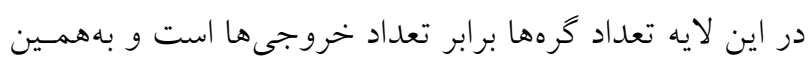

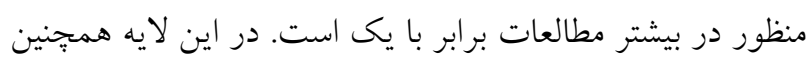

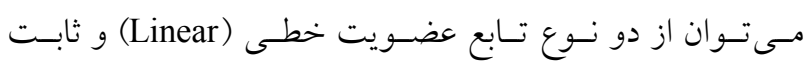
استفاده كرد: (Constant) $\mathrm{Q}_{\mathrm{i}}^{\diamond}=\sum \overline{\mathrm{w}}_{\mathrm{n}} \mathrm{f}_{\mathrm{i}}=\frac{\sum \mathrm{w}_{\mathrm{i}} \mathrm{f}_{\mathrm{i}}}{\sum \mathrm{w}_{\mathrm{i}}}$ در نهايت مى توان خروجى كل را بهصورت تركيسب خطى از پارامترهاى نتيجه مطابق رابطه (ب (1) بيان كرد:

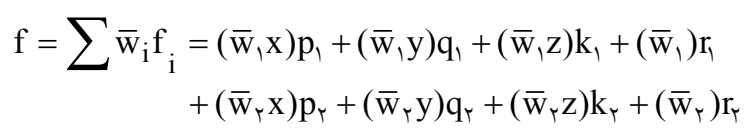

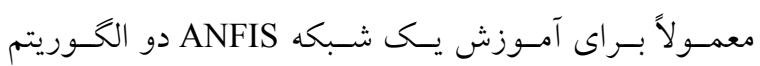

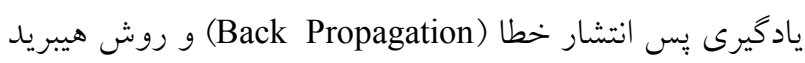

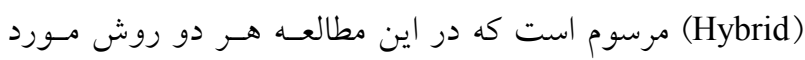

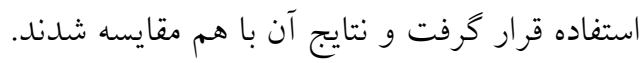
معيارهاى ارزيابى قواعد بهرهبردارى

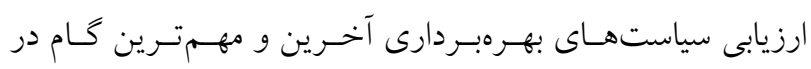




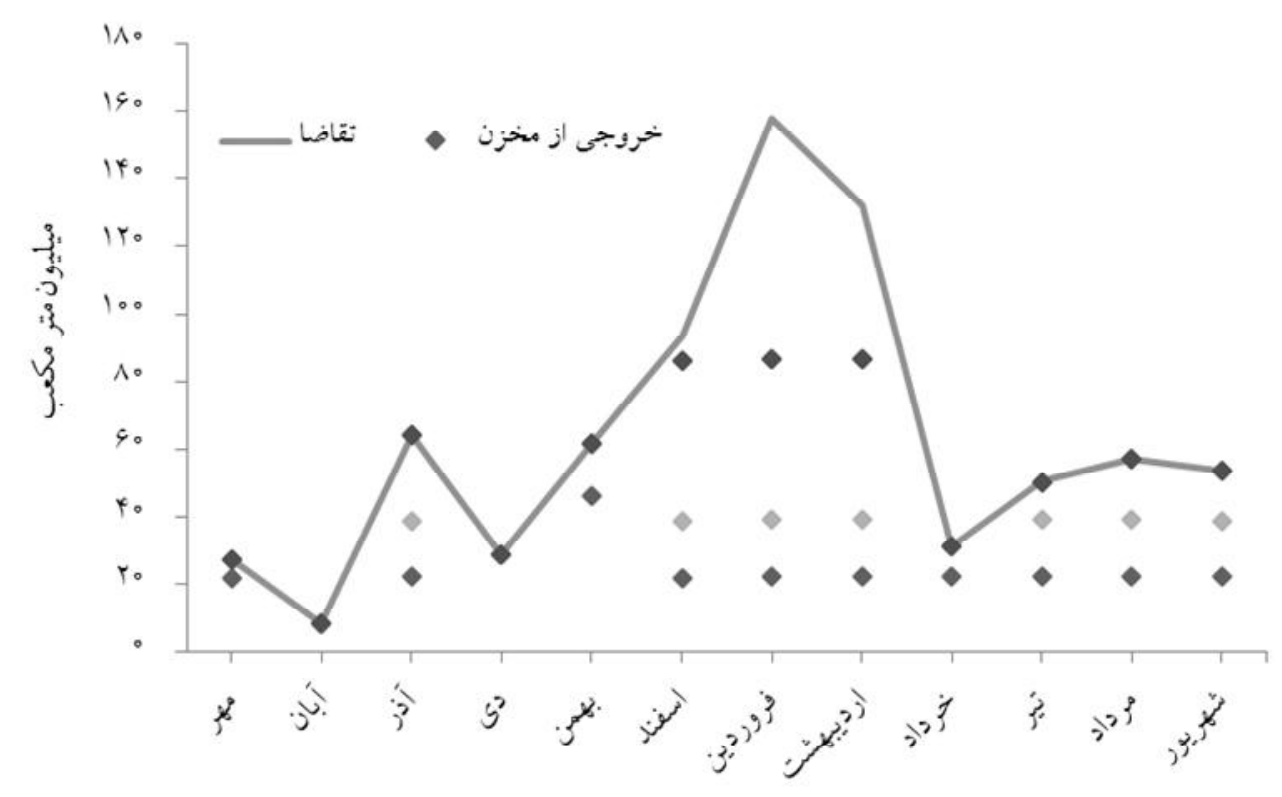

شكل r. نمودار نياز ماهانه و حجم آب رها شده از مخزن براساس مدل بهرهبردارى بهينه

$S=\beta \alpha(1-\lambda)$

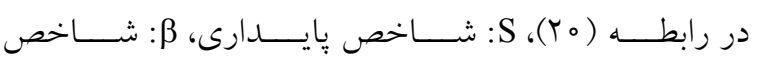

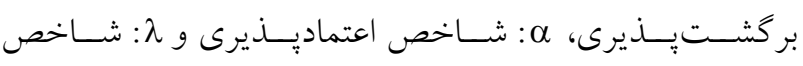
آسيب پِيرى است. مقدار بيشتر اين شاخص، نشاندهنده برترى لري

قاعده بهرهبردارى از مخزن است (Tه).

\section{نتايج}

قبل از استخراج قواعد بهرهبردارى از مخـزن، بـهمنظـور تعيسين ميزان بهينه خروجى از سد، ابتدا ميزان رهاسـازى آب از مخـزن لهرن

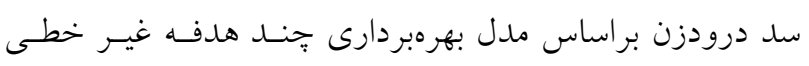
بهينهيابى شد. در شكل (r)، نياز ماهانه و حجم آب رها شده از مخزن، براساس مدل بهرهبردارى بهينه آورده شده است. همـانطوركــه از نمــودار فــوق مشـــص اســت، مــدل

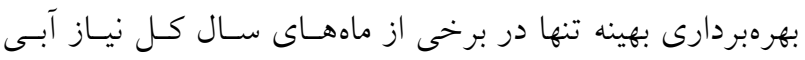

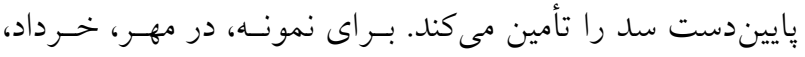
تير، مرداد و شهريورماه، كل نيـاز آبسى تـأمين مسىشـود، امـا در

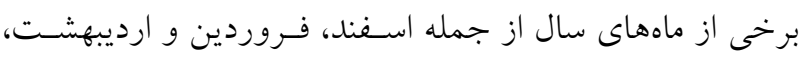

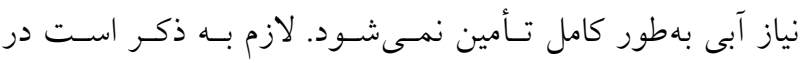

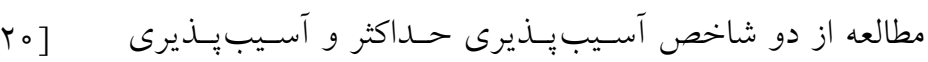
متوسط مطابق روابط VIV، I | و 19 استفاده شد (Yo): $\lambda_{\operatorname{Max}}=\operatorname{Max}\left(\lambda_{\operatorname{Max} t}\right) \quad \mathrm{t}=1, r, \ldots, \mathrm{m}$

$\lambda_{\text {Max t }}=\left[\operatorname{Max}\left(D_{t}-R_{t i}\right), i=1, r, \ldots ., T\right] / D_{t}$

$\lambda_{\text {Avg }}=\frac{\sum_{i=1}^{m} \lambda_{\text {Max } t}}{m}$

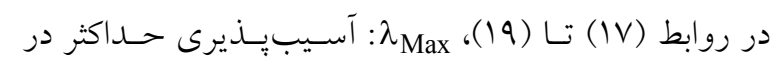
طول دوره برنامهريزى، Maxt

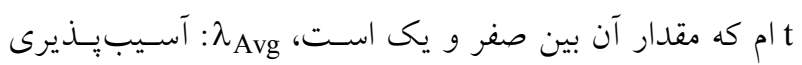
متوسط، T: تعداد كل سالهاى شبيهسـازى، m: تعـداد مـاههـاى سال و برابر با با او i : تعداد سال است. ايـن معيـار مقــدار بـين صـفر و يـك دارد و مقــدار كمتـــ آن حسـاكى از برتـرى قاعـده بهرهبردارى نسبت به ساير قواعد است (Yه).

شاخص پِيدارى (Sustainability)

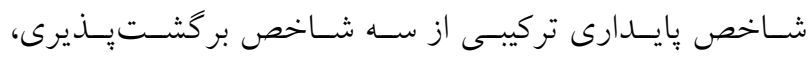
اعتماديذيرى و آسيب بِذيرى است كه بهصورت رابطه (ب0) بيان

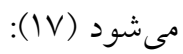


جدول ا. قواعد بهرهبردارى از مخزن سد درودزن با استفاده از روش رگرسيونى

\begin{tabular}{|c|c|c|c|c|c|c|c|c|c|c|}
\hline \multicolumn{5}{|c|}{ آمارههاى تشخيص } & \multicolumn{5}{|c|}{ ضرايب } & \multirow{2}{*}{ مدل } \\
\hline RMSE & $\mathrm{F}$ & $\overline{\mathrm{R}}^{r}$ & SBC & AIC & $\mathrm{S}_{\mathrm{t}-1}^{r}$ & $S_{t-1}$ & $\operatorname{In}_{\mathrm{t}}^{r}$ & $\operatorname{In}_{\mathrm{t}}$ & $\alpha$ & \\
\hline $4 \pi / \mu q$ & $109 / 11^{* * * *}$ & $\circ / \mu V$ & $10 / \mu q$ & $1 \circ \pi \Delta$ & - & - & - & $0 / 44^{* * * *}$ & $r V / \mu q^{* * * *}$ & 1 \\
\hline$\varphi \circ / 00$ & $9 N / 01^{* * *}$ & O/AT & س & $10 / T V$ & - & - & $-0 / 001^{* * * *}$ & $\circ / \circ \wedge 9^{* * *}$ & $\mid Y / V e^{* * * *}$ & r \\
\hline $01 / 99$ & $1 \pi / \wedge 9^{* * *}$ & $0 / 09$ & $10 / v 9$ & $10 / V 9$ & - & $-0 / 99^{* * *}$ & - & - & $9 \circ / 14^{* * * *}$ & r \\
\hline $01 / 09$ & $10 / T \Lambda^{* * *}$ & $\circ / 09$ & $10 / v 9$ & $10 / Y^{4}$ & $\circ / \circ \circ \circ Y^{* *}$ & $-0 / \mathcal{G}^{\prime * * * *}$ & - & - & $1 r r / q^{* * * *}$ & r \\
\hline$F / T q$ & $\Lambda F / \Delta \Lambda^{* * * *}$ & $\circ / M V$ & IO/KTD & $10 / 49$ & - & $-0 / 01$ & - & o/AYY & $|T / 4|^{* * * *}$ & $\Delta$ \\
\hline
\end{tabular}



در خصوص سيستم اسـتنتاج فـازى، براسـاس نتـايج مـدل

بهرهبردارى جند هدفه غير خطى از ســـ درودزن، بـهـ بِيسروى از

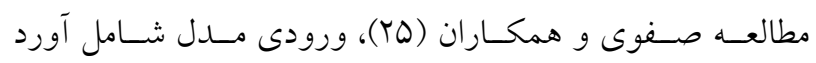

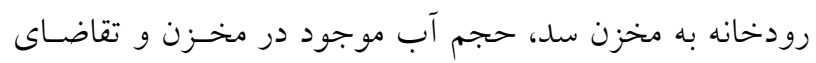
آب در ياييندست سد و نتيجه مدل نيز حجم آب رهـا شـده از مخزن سد، در نظر كرفتـه شـد. بـراى متغيـرهـاى ورودى آورد رودخانه و حجم مخزن در دوره مورد بررسى (110 مـاه) يسنج

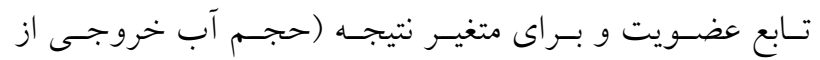
مخزن)، هفت تابع عضويت در نظر گرفته شد. حداكثر و حداقل مقدار هر متغير بهعنوان حد بالا و يايين توابع عضـويت "بسـيار كم" و "بسيار زياد" در نظر كرفته شد. براى متغيرهـاى ورودى شامل آورد رودخانه و حجم مخزن نيز، ينج تابع عضويت شامل "بسيار كم"، "بسيار زياد"، "كم"، "زياد" و "متوسـط" و بــراى متغير نتيجه (خروجى از مخـزن)، هفــت تـابع عضـويت شـامل "بسيار كم"، "بسيار زياد"، "كم"، "زياد"، "نسبتاً زياد"، " نسبتاً كم" و "متوسط" در نظر كرفته شد. شكل (Y)، توابـع عضـويت را در خصوص متغيير نتيجه تحت شرايط نرمال نشان مسىدهـد. در خصوص تقاضاى باييندست سل، سه تابع عضـويت شـامل

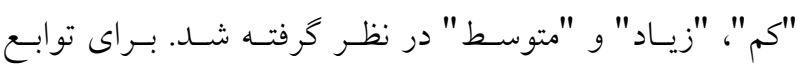
عضويت "كم" و "زياد"، از تــابع عضـويت ذوزنقـهاى و بــراى تابع عضويت "متوسط" از تابع مثلثى استغاده شد. در ايـن مطالعـهـ بــراى دسـتهبنــى توابـع مـذكور از روش

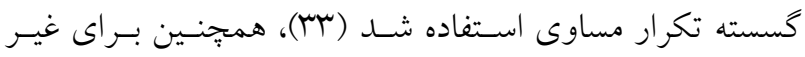
فازى كردن دادهها، از روش مركز ثقل استفاده شـــ. بـا بررسىى
مجمـوع VD درصــ از نيـازآبى يـاييندسـت بـر اسـاس مــل بهرهبردارى بهينه از مخزن سل، تـأمين مسىشـود. بـا ايسن حسال بهدليل آنكه تقاضـاى آب شهرى و صـنعت در مــل بهينـه در اولويت قرار دارند، نياز آبى اين دو بخش در تمام ماههاى سـال بهور كامل تأمين شــده اسـت. در ادامـه براسـاس نتـايج مــل بهينهيابى، قواعد بهرهبردارى از مخزن سد درودزن با استفاده از روش رگرسيونى استخراج شد كه نتايج آن در جدول (1) آورده شده است. با توجـه بـه نتـايج جــدول (1)، مــدل شـماره دو بـهدليـل معنــى دارى تمــام ضــرايب، آمــاره F و بــالابودن ضــريب

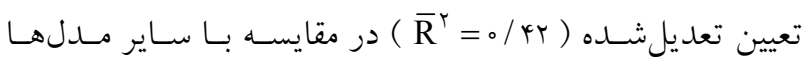

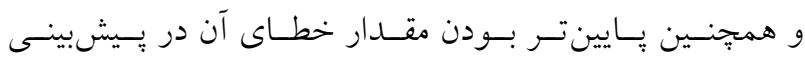
Root of Mean Square Error (RMSE)) فرمان سد درودزن، انتخاب شد، همجنين معيارهـاى تشخيصسى آكائيك (ACI) و شوارتز بيـزين (SBC) بـراى مـــل دوم داراى كمترين مقدار بوده و تأييد كننده برترى مدل دوم نسبت به ساير

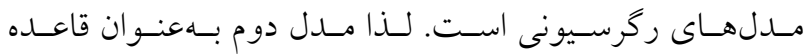

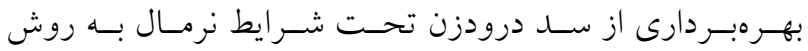
رگرسيونى انتخاب شد. در ايسن مــل، ميـزان رهاسـازى آب از

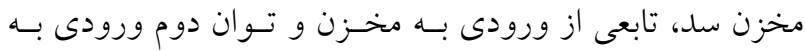

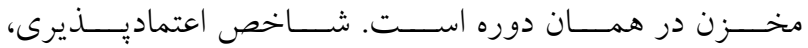

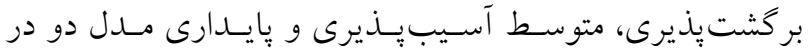
روش رگرسيونى بهترتيب برابـر بـا لهاهـ، ساع/ه، اس/ه و و است. 

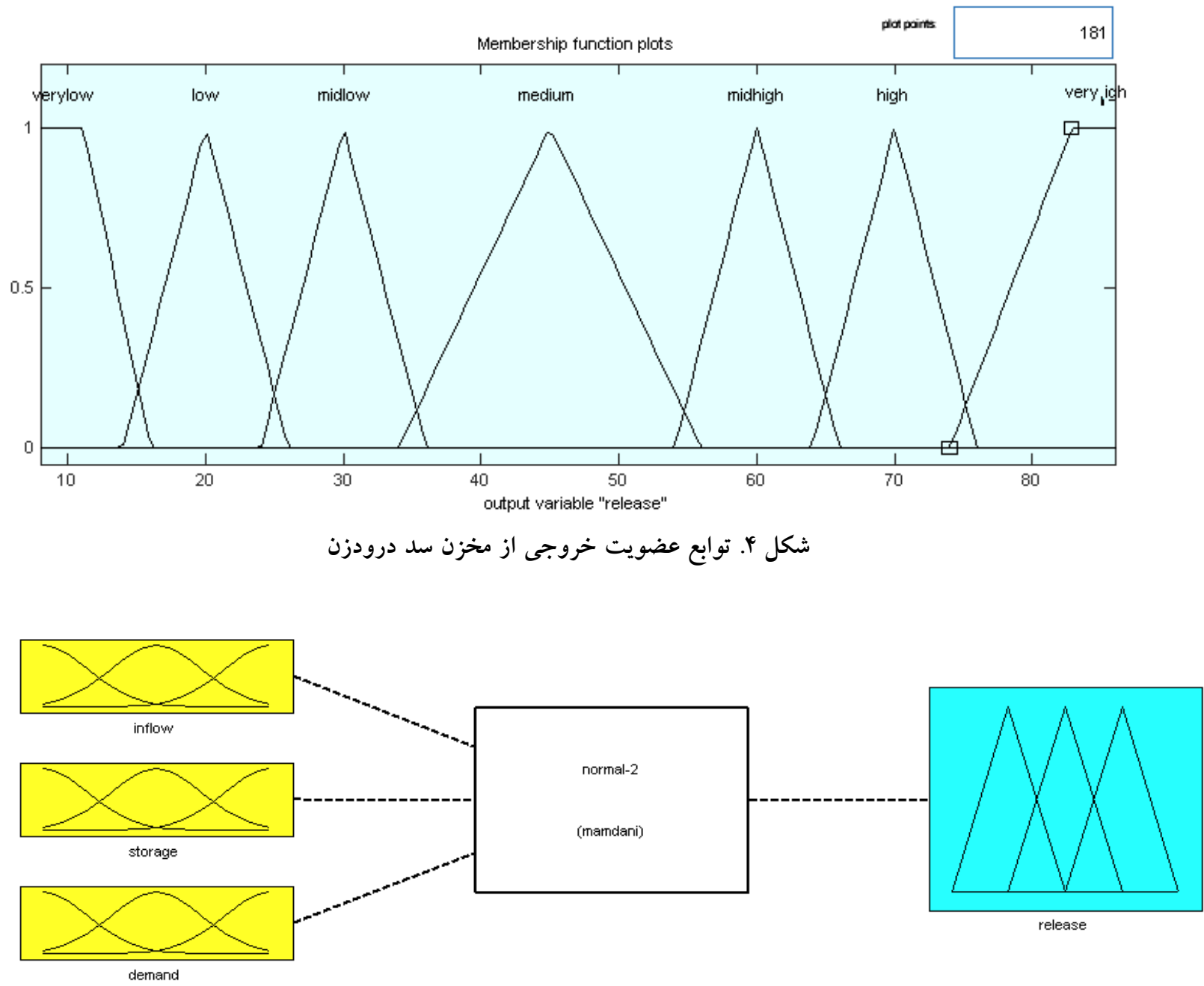

شكل ه. نماى كلى ساختار منطق فازى مدل دوم

طراحى شد. در اين سيستم ورودى و خروجسى كـه تركيبى از حجم مخزن، آورد رودخانه، تقاضاى باييندست ونست و خروجسى از مخزن است، بهصورت شكل (9) است.

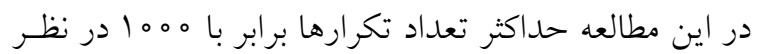
كرفته شد. مقايسه مدلهـاى مختلـف ANFIS نشـان داد كـه از

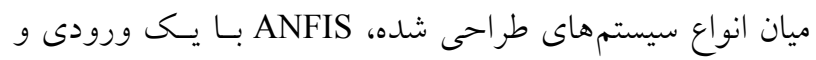

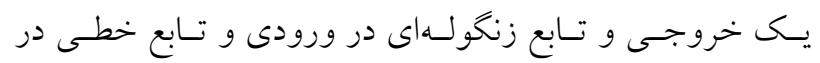

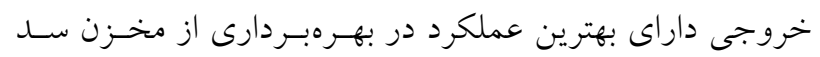
درودزن است. لازم بهذكر است كه در اين مطالعه براى هر مـاه،

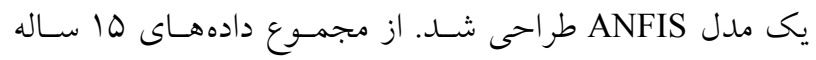

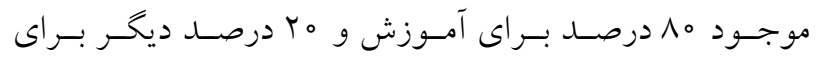

نتايج مدل بهرهبردارى بهينه مبتنى بر مدل بهرهبردارى غير خطى

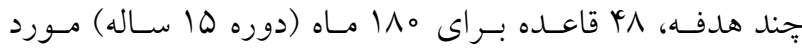
بررسى، به كار كرفته شد. در شكل (Q)، نماى كلى ساختار منطق فازى مورد استفاده در اين مطالعه آورده شده است.

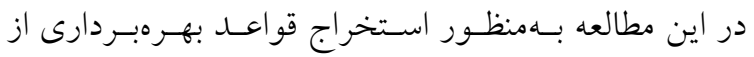

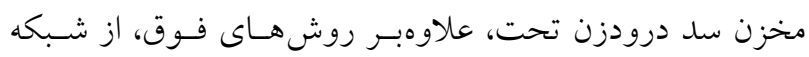

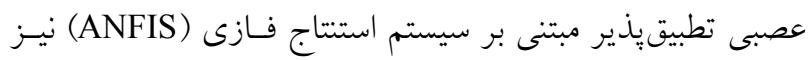

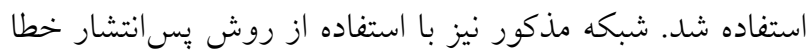

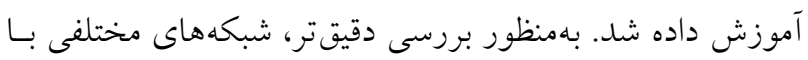
ورودى هاى متفاوت طراحى شدند. همجنين با بيروى از مطالعه

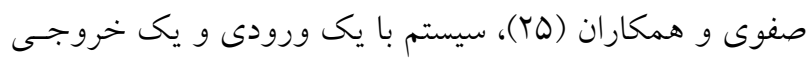




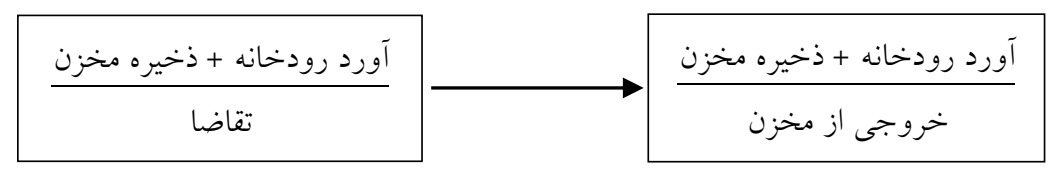

ورودى

خروجى

\section{شكل 9. ورودى و خروجى ANFIS}

شاخص بين مدلهاى مختلف بهجز بهرهبـردارى فعلى، بسيار اندى است.

براساس شاخص حداكثر آسيبِيذيرى كه در ستون جهارم

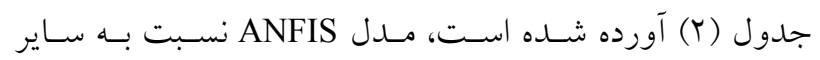

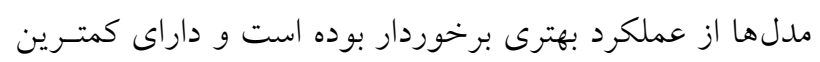

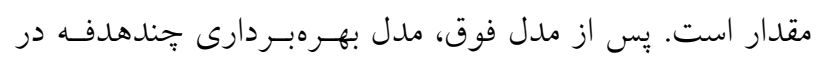

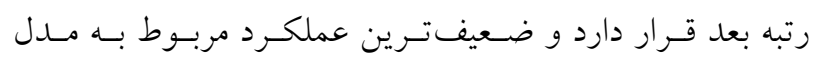

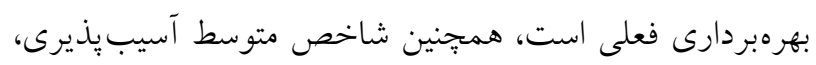

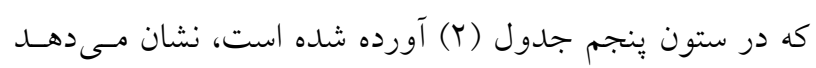

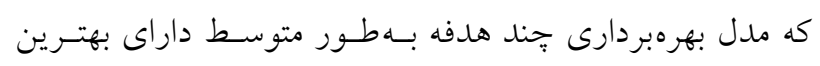

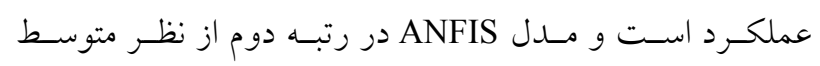
آسيب نيذيرى قرار دارد.

با توجه به نتايج متفاوت حاصل از شاخص دهاى مختلف، از

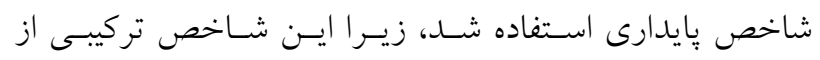

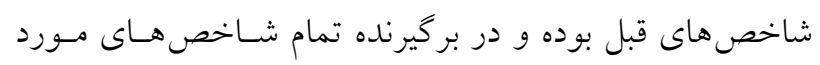

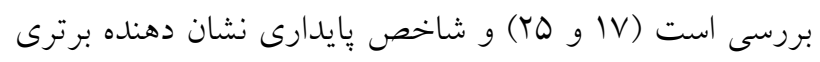
مدل ANFIS در مقايسه با ساير مدلها است.

\section{نتيجه گيرى}

در اين مطالعه با استفاده از دادههـاى ماهانـهـ يــ دوره بـانزده

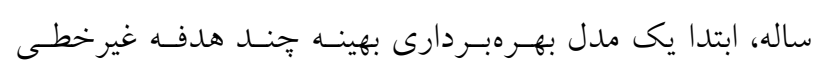

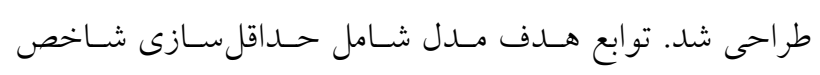

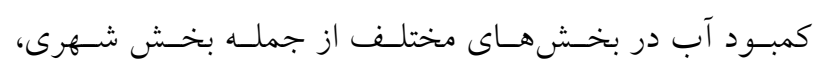
صنعتى، زيستمحيطى و كشاورزى در نظر گرفته شد. در ادامـهـ

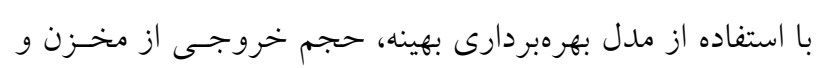

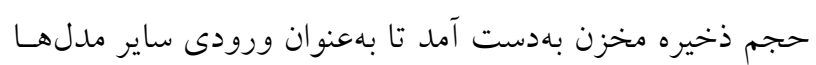

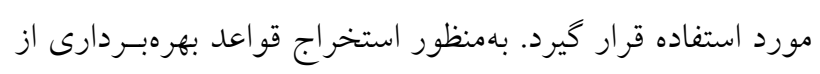

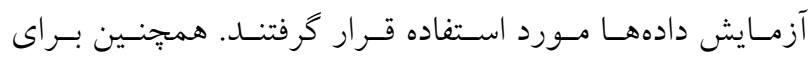

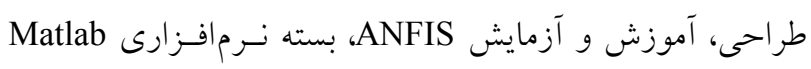

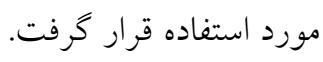

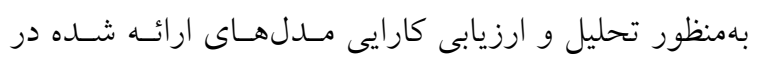

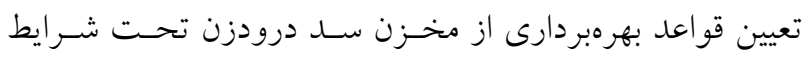

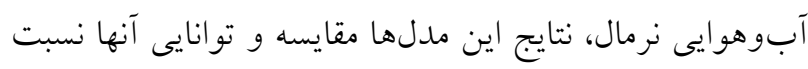

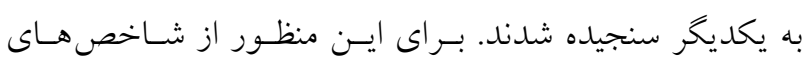

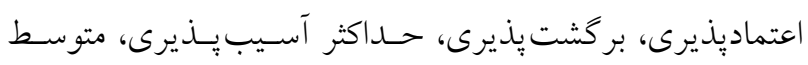

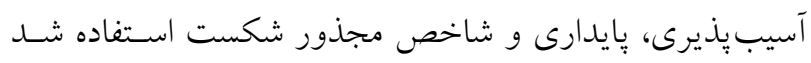

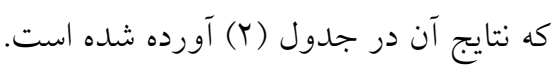

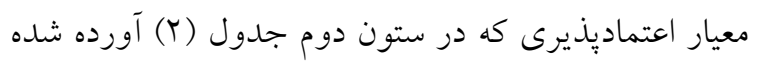

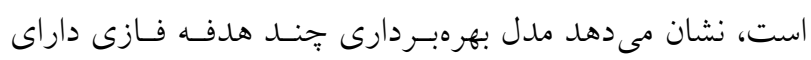

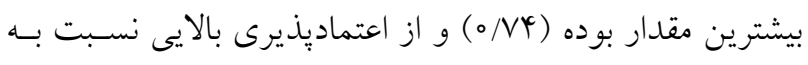

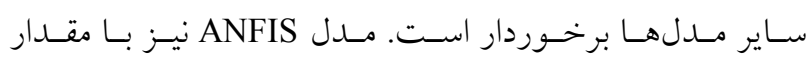

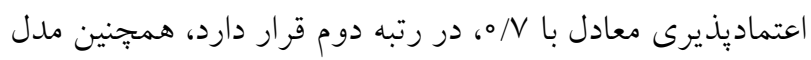

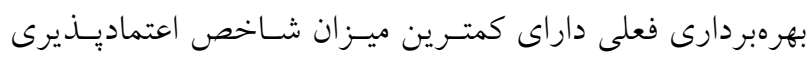

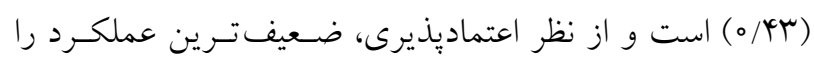

دارد.

شاخص بر گشتيذيرى كه در ستون سوم جدول (Y) آورده

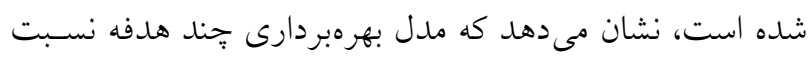

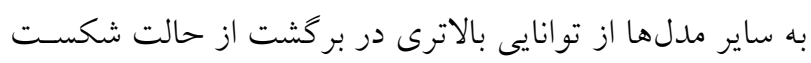

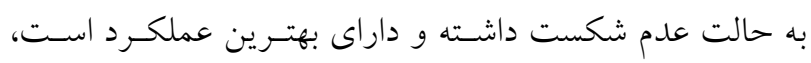

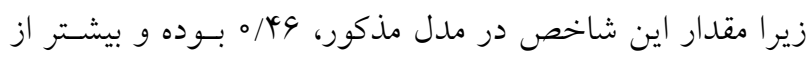

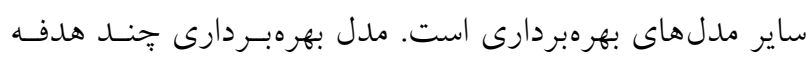

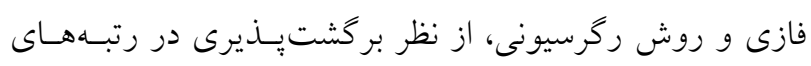

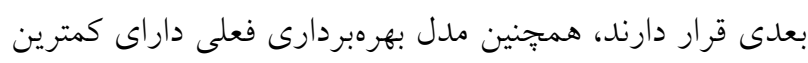

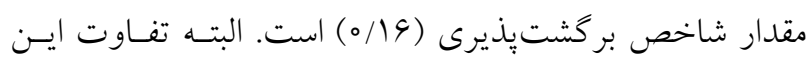


جدول r. نتايج ارزيابى مدلهاى بهرهبردارى از مخزن سد درودزن

\begin{tabular}{|c|c|c|c|c|c|}
\hline 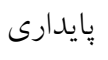 & متوسط آسيبيذيرى & حداكثر آسيبيذيرى & بر گشتيذ يرى & اعتماديذ يرى & شاخص \\
\hline $0 / 0 Y$ & $0 / 91$ & $\circ / 99$ & $0 / 19$ & L & بهرهبردارى فعلى \\
\hline $0 / r \mu$ & $\circ / 10$ & $0 / 9 \mu$ & $0 / 49$ & $\circ / 0 / Q V$ & بهرهبردارى جند هدفه \\
\hline $0 / \pi 1$ & $\circ / \mu$ & $\circ / M$ & $\circ / 40$ & $\circ / V^{4}$ & جند هدفه فازى \\
\hline $0 / 19$ & $0 / \mu$ & $\circ / \Lambda 1$ & س & .190 & روش رگرسيونى \\
\hline $0 / T 9$ & (1/1 - (1) & $\circ / 4 \circ$ & OMY & $\circ / V_{0}$ & ANFIS \\
\hline
\end{tabular}

روشهاى مختلف نيز از شـاخصهـاى عملكـــد مخـزن شـامل

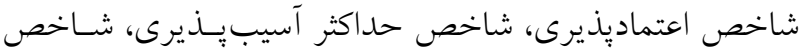

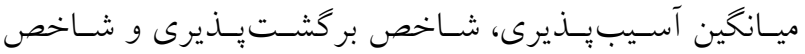

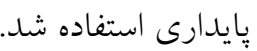
نتايج تحقيق حاضر نشان داد كه براساس شاخص هاى فوق،

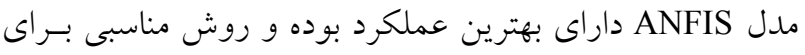

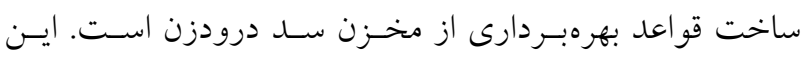

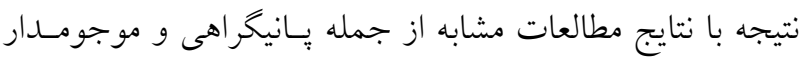

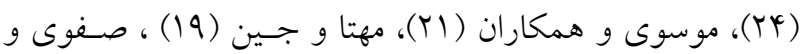

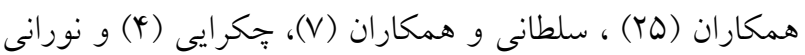

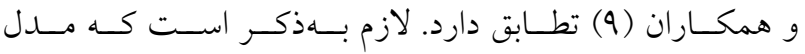
بهرهبردارى فعلى، داراى كمترين مقدار براى شـاخص بايسـارى

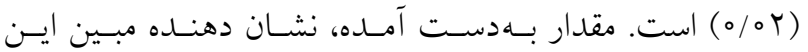

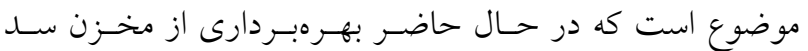

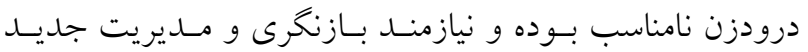

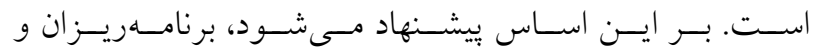
سياست كذاران در زمينه مديريت منابع آبى، بـا اسـتفاده از مـدل تخصيص بيشنهادى، نسـبت بـه رهاسـازى آب از ســ درودزن جهت مصارف مختلف اقدام كنند.

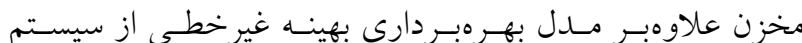

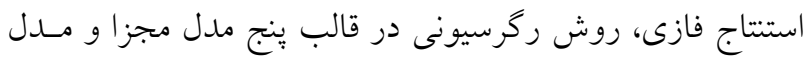
ANFIS از ميان مدلهاى مختلف رگرسيونى، مدل درجه دوم كه در

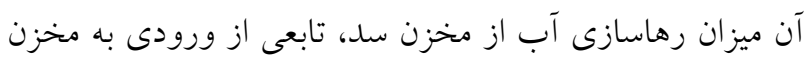

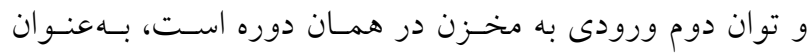

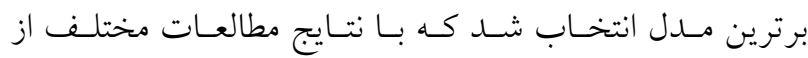

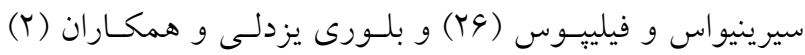

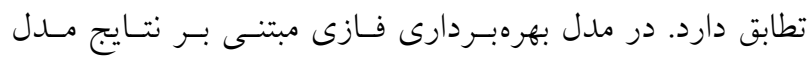

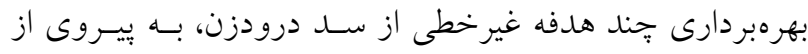

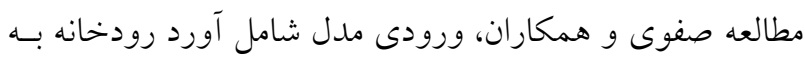
مخــزن ســ، حجــم آب موجـود در مخــزن، تقاضـاى آب در

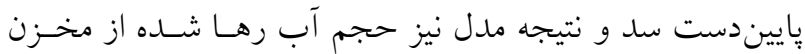
سل، در نظر كرفته شد. علاوهبر روشهاى فـوق، مــل ANFIS نيز در اين تحقيق مورد استفاده قرار گرفت. مقايسـه مــلهــاى

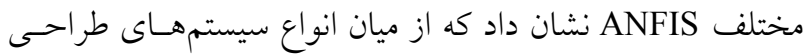

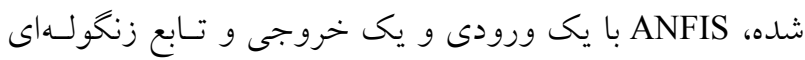

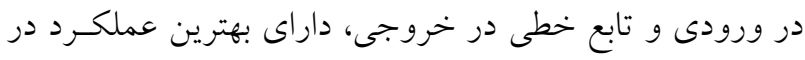

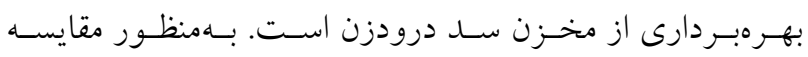

\section{منابع مورد استفاده}

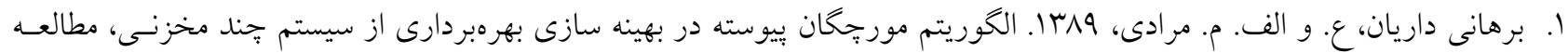

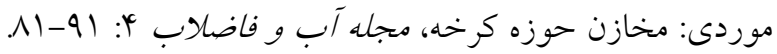

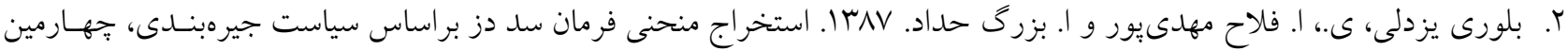

$$
\text { كنكره ملى مهندسى عمران. تهران. }
$$




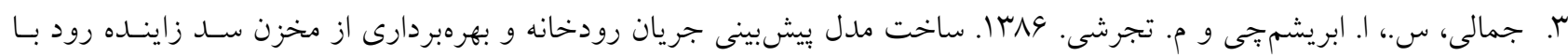

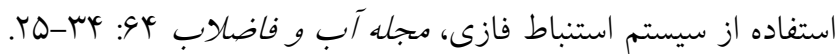

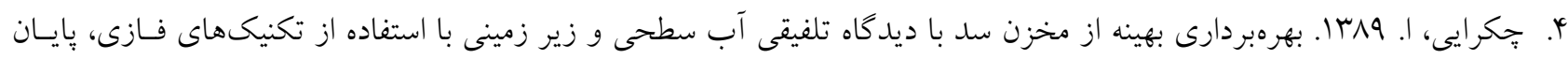

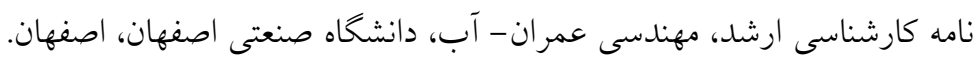

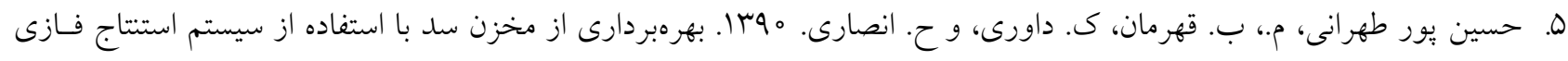

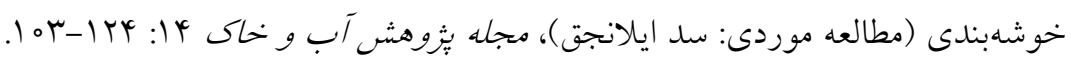

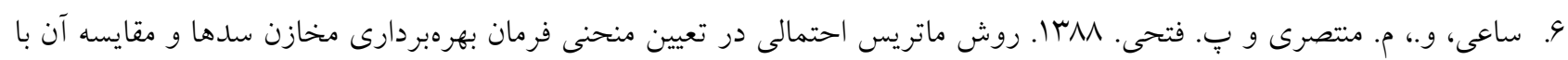

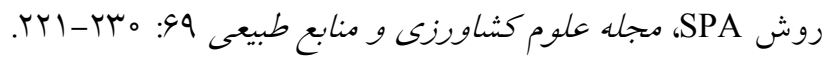

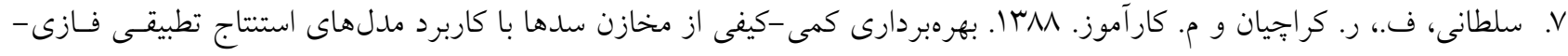

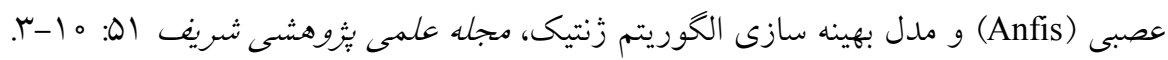

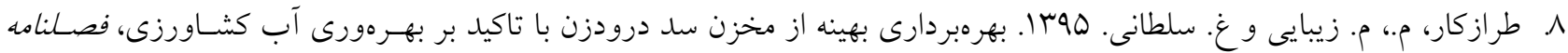
|قتصاد كشاوززى و توسعه 99: DQ-OD.

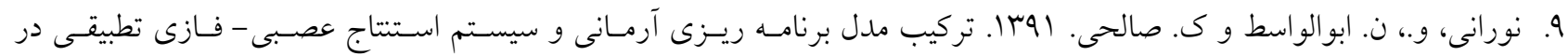

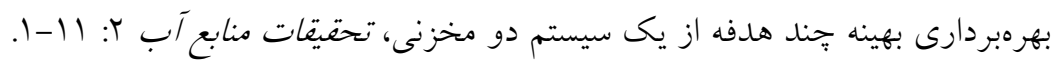

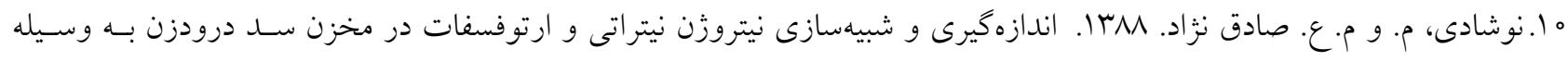

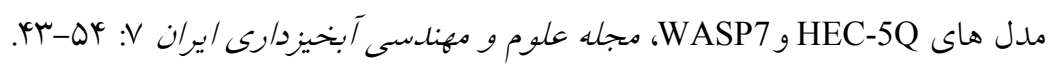

11. Chang, F. J., L.Chen and L. C. Chang. 2005. Optimizing the reservoir operating rule curves by genetic algorithms, Hydrological Processes 19: 2277-2289.

12. Hashimoto, T., J. R. Stedinger and D. P. Loucks. 1982. Reliability, esilience, and vulnerability criteria for water resource system performance evaluation, Water Resources Research 18: 14 - 20.

13. Jang, J. R. and C. Sun. 1993. Predicting chaotic time series with fuzzy if-then rules, In: Proceeding of the IEEE Conferance on Fuzzy System, San Francisco. PP: 1079:1084.

14. Karamouz, M., M. H. Houck and J. W. Delleur. 1992. Optimization and simulation of multiple reservoir systems Journal of Water Resources Planning and Management 118: 71-81.

15. Keshavarzi, A. and S. H. Nabavi. 2007. Dominant discharge in the Kor river, upstream of Dorodzan dam, Fars Province, Iran, Trends in Applied Sciences Research 2: 158-164.

16. Liu, P., SH. Guo, X. Xu and J. Chen. 2011. Derivation of aggregation-based joint operating rule curves for cascade hydropower reservoirs, Water Resources Management 25: 3177-3200.

17. Louks, D. P. 1997. Quantifying trend in system sustainability, Hydrological Sciences Journal 42:513-530.

18. Mamdani, E. H. 1997. Application of fuzzy logic to approximate reasoning using linguistic system, Fuzzy Sets and Systems 26: $1182-1191$.

19. Mehta, R. and S. K. Jain. 2009. Optimal operation of a multi-purpose reservoir using neuro-fuzzy technique, Water Resources Management 23: 509-529.

20. Milutin, D. and J. J. Bogardi. 1995. Reliability criteria in the assessment of a multiple - reservoir operational strategy under Mediterranean conditions, Water resources management under drought or water shortage conditions. In: Proceedings of the EWRA 95 Symposium, Nicosia, Cyprus.

21. Mousavi, S. J., K. Ponnambalam and F. Karray. 2007. Inferring operating rules for reservoir operations using fuzzy regression and ANFIS, Fuzz. Fuzzy Sets and Systems 158: 1064-1082.

22. Nikoo, M. R., A. Karimi, R. Kerachiyan, H. Poorsepahy-Samian and F. Daneshmand. 2013. Rules for optimal operation of reservoir-river-groundwater systems considering water quality targets: application of M5P model, Water Resources Management 27:2771-2784.

23. Ojha, A. K. and K. K. Biswal. 2009. Lexicographic multi-objective geometric programming problem, International Journal of Computer Science Issues 4(2): 20-24.

24. Panigrahi, D. P. and P. P. Mujumdar. 2000. Reservoir operation modeling with fuzzy logic, Water Resources Management 14:89-109. 
25. Safavi, H. R., I. Chakraei, A. Kabiri-Samani and M. H. Golmohammadi. 2013. Optimal reservoir operation base on conjunctive use of surface water and groundwater using Neuro-fuzzy system, Water Resources Management 27: 4259-4275.

26. Srinivasan, K. and M. C. Philipose. 1996. Evaluation and selection of hedging policies using stochastic reservoir simulation. Water Resources Management 10: 163-188.

27. Takagi, T. and M. Sugeno. 1983. Derivation of fuzzy control rules from human operator's control action, In: Proceeding of the International Federation of Automatic Control (IFAC) Symposium Knowledge Representation and Decision Analysis, PP. 55-60.

28. Tarazkar, M. H. and A. Esmaeili. 2011. A neuro-fuzzy model for Prediction of agricultural commodity price: the case of corn price in Iran. In: Proceding of the World Congress of International Fuzzy Systems Association 2011 and Asia Fuzzy Systems Society International Conference 2011, Surabaya-Bali, Indonesia,

29. Tarazkar, M. H., G. R. Soltani and M. Zibaei. 2015. Optimal operation of multi-reservoir system of Bakhtegan basin, Fars province, Iran. In: Proceeding of the International Conference on Management, Economics and Accounting, Istanbul, Turkey.

30. Tilmant, A., P. Fortemps and M. Vanclooster. 2002. Effect of averaging operator in fuzzy optimization of reservoir operation, Water Resources Management 16: 1-22.

31. Votruba, L. and V. Broza. 1989. Function in reservoirs, Water Management in Reservoirs 33: 343-367.

32. Wang, L., L. Fanf and K. W. Hipel. 2008. Basin-wide cooperative water resource allocation, Europ. European Journal of Operational Research 190: 798-817.

33. Yang, Y. and G. I. Web. 2009. A Comparative Study of Discretization Methods for Naive-Bayes Classifiers, Machine Learning 74: 39-74. 


\title{
Determining the Operating Rules Of Doroodzan Reservoir Using the Adaptive Network Fuzzy Inference System (ANFIS)
}

\author{
M. H. Tarazkar ${ }^{1 *}$, M. Zibaei ${ }^{1}$, G. R. Soltani ${ }^{1}$ and M. Noshadi ${ }^{2}$
}

(Received: December 31-2016 ; Accepted: August 14-2017)

\begin{abstract}
Nowadays, water resource management has been shifted from the construction of new water supply systems to the management and the optimal utilization of the existing ones. In this study, the reservoir operating rules of Doroodzan dam reservoir, located in Fars province, were determined using different methods and the most efficient model was selected. For this purpose, a monthly nonlinear multi-objective optimization model was designed using the monthly data of a fifteen-year period (2002-2017). Objective functions were considered as minimizing water scarcity index in municipal, industrial, environmental and agricultural sectors. In order to determine the operating rule curves of reservoir, in addition to the nonlinear multi-objective optimization model, the methods of ordinary least-squares regression (OLS), fuzzy inference system and adaptive network fuzzy inference system (ANFIS) were used. Also, the reliability, resiliency, vulnerability and sustainability criteria were used to compare the different methods of reservoir performance rules. The results showed that ANFIS model had the higher sustainability criterion $(0.26)$ due to its greater reliability $(0.7)$ and resilience $(0.42)$, as well as its lower vulnerability $(0.13)$, thereby showing the best performance. Therefore, ANFIS model could be effectively used for the creation of Doroodzan reservoir operation rules.
\end{abstract}

Keywords: Rule Curve, Fuzzy Inference System, Neuro-Fuzzy Network, Reservoir Operation Index

1. Department of Agricultural Economics, College of Agriculture, Shiraz University, Shiraz, Iran.

2. Department of Water Engineering, College of Agriculture, Shiraz University, Shiraz, Iran.

*: Corresponding Author, Email: Tarazkar@shirazu.ac.ir 